\title{
Strain gradient effects on concrete stress-strain curve
}

1 Jun Peng MPhil

PhD Student, Department of Civil Engineering, University of Hong Kong, Hong Kong
2 Johnny Ching Ming Ho PhD, MHKIE, MIEAust, CPEng Assistant Professor, Department of Civil Engineering, University of Hong Kong, Hong Kong
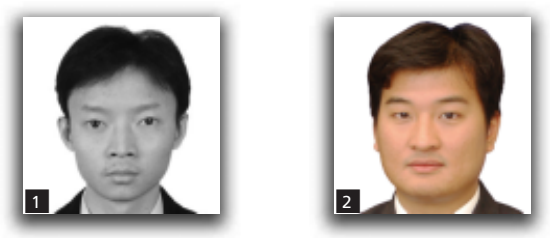

The stress-strain characteristic of concrete developed in flexure is one of the essential parameters for the ultimate flexural strength design of reinforced concrete (RC) members. Currently, the stress-strain curve of concrete developed in flexure is obtained by scaling down the uniaxial stress-strain curve. In current RC design codes, it is represented by an equivalent rectangular concrete stress block depending solely on the concrete strength. By comparing the theoretical strength evaluated for the stress block with the measured strength, the authors found that current codes underestimate the actual flexural strength of RC beams and columns by $9 \%$ and $19 \%$, respectively. Since the underestimation is different for beams and columns, which are subjected to different strain gradients at ultimate, it is suggested that the maximum concrete stresses developed in flexure should depend also on strain gradient. The effects of strain gradient on the concrete stress developed in flexure were investigated in this work by testing RC columns under concentric and eccentric axial loads or horizontal loads. The concrete stress-strain curves of the eccentrically/horizontally loaded specimens were derived by modifying those of concentrically loaded counterparts based on axial force and moment equilibriums. The results indicate that the maximum concrete stress developed in flexure depends significantly on strain gradient. Formulas were developed to correlate the maximum and equivalent concrete stresses developed in flexure to the strain gradient. Their applicability was verified by comparing the results with measured flexural strengths of RC beams and columns.

\section{Notation}

$A_{\mathrm{c}} \quad$ area of concrete compression zone

$A_{\mathrm{g}} \quad$ column cross-section area

$A_{\mathrm{s}} \quad$ area of steel bar

$b \quad$ width of cross-section

c neutral axis depth

$d \quad$ effective depth of column section

$d_{i} \quad$ distance of longitudinal steel bar to extreme compressive fibre or effective depth of cross-section in Equations 3, 4 and 5

$E_{\mathrm{s}} \quad$ Young's modulus of steel bar

$f_{\text {av }}$ average concrete compressive stress over compression area in flexural members

$f_{\mathrm{c}}^{\prime} \quad$ uniaxial concrete compressive strength represented by cylinder strength

$f_{\text {cu }} \quad$ uniaxial concrete compressive strength represented by cube strength

$f_{\max }$ maximum concrete compressive stress developed under flexure

$f_{\mathrm{s}} \quad$ stress of steel bar in Equations 3, 4 and 5 $f_{\mathrm{y}} \quad$ yield strength of steel bar

$h$ height of cross-section

$k_{1} \quad$ ratio of average stress $\left(f_{\text {av }}\right)$ over compression area to maximum stress developed under flexure $\left(f_{\max }\right)$

$k_{2} \quad$ ratio of distance between extreme compressive fibre and resultant force of compressive stress block $\left(\boldsymbol{P}_{\mathrm{c}}\right)$ to that between the same fibre to the neutral axis $(c)$

$k_{3} \quad$ ratio of $f_{\max }$ to concrete cube strength $f_{\text {cu }}$

$k_{3}^{\prime} \quad$ ratio of $f_{\max }$ to the maximum uniaxial concrete strength $\sigma_{\max }$

$\boldsymbol{M}$ moment or flexural strength

$\boldsymbol{M}_{\mathrm{ACI}}$ moment calculated based on ACI 318 (ACI, 2008)

$\boldsymbol{M}_{\mathrm{EC}}$ moment calculated based on Eurocode 2 (CEN, 2004)

$\boldsymbol{M}_{\mathrm{NZ}}$ moment calculated based on NZS 3101 (SNZ, 2006)

$\boldsymbol{M}_{\mathrm{p}}$ moment calculated based on the proposed values of equivalent rectangular concrete stress block parameters obtained in this study

$\boldsymbol{M}_{\mathrm{t}} \quad$ measured moment capacity

$n \quad$ number of longitudinal steel bars

$\boldsymbol{P}$ axial load 
$\boldsymbol{P}_{\mathrm{c}} \quad$ resultant force of concrete compressive stress block

$\alpha \quad$ ratio of equivalent concrete compressive stress developed under flexure to concrete cube strength $\left(f_{\mathrm{cu}}\right)$

$\beta \quad$ ratio of height of equivalent rectangular concrete compressive stress block to neutral axis depth

$\varepsilon \quad$ concrete strain

$\varepsilon_{\mathrm{cu}} \quad$ ultimate concrete strain at extreme compressive fibre measured at maximum load of eccentrically or horizontally loaded specimen

$\rho_{\mathrm{s}} \quad$ longitudinal reinforcement ratio

$\sigma \quad$ concrete stress

$\sigma_{\max }$ maximum concrete compressive stress developed in concentrically loaded specimen

$\phi \quad$ strain gradient

\section{Introduction}

In the current reinforced concrete (RC) design codes, the concrete stress distribution within the compression zone of a typical RC section subjected to bending at ultimate state is non-linear, as shown in Figure 1. This stress-strain curve of concrete is derived by scaling down the stress-strain curve of concrete developed in uniaxial compression to $67 \%$ of the compressive strength of standard concrete cubes. This factor, which was derived from converting $85 \%$ of standard concrete cylinder strength to the respective cube strength proposed by Hognestad et al. (1955), is to account for the different concrete strengths developed in standard concrete cubes, $f_{\text {cu }}$, and real columns. In ultimate flexural strength design of RC sections, the non-linear concrete stress distribution is represented by a concrete stress block defined by three parameters, $k_{1}, k_{2}$ and $k_{3}$ (Hognestad et al., 1955; Ibrahim and MacGregor, 1996, 1997; Kaar et al., 1978; Tan and Nguyen, 2004, 2005). $k_{1}$ is the ratio of average stress, $f_{\text {av }}$, over the compression zone to maximum stress developed under flexure, $f_{\max }, k_{2}$ is the ratio of distance between the extreme compressive fibre and the resultant force of the stress block $\left(\boldsymbol{P}_{\mathrm{c}}\right)$ to that between the same fibre to the neutral axis $(c)$ and $k_{3}$ is the ratio of $f_{\max }$ to uniaxial concrete cube (or cylinder) strength. This stress block was further simplified to an equivalent rectangular concrete stress block (Hognestad, 1957; Kriz, 1959; Mattock et al., 1961; Whitney, 1940) to facilitate practical flexural strength design of RC members, which are currently being adopted in RC design codes such as Eurocode 2 (CEN, 2004), NZS 3101 (SNZ, 2006) and ACI 318 (ACI, 2008).

The equivalent rectangular concrete stress block (Figure 1(e)) is defined by two parameters, $\alpha$ and $\beta$ : $\alpha$ is the ratio of the equivalent concrete compressive stress developed under flexure to the concrete cube strength, $f_{\mathrm{cu}} ; \beta$ is the ratio of the height of the equivalent rectangular concrete stress block to the neutral axis depth (c). An ideal equivalent rectangular concrete stress block could give an exact representation of the magnitude and location of the resultant concrete compressive force and thus the flexural strength of RC members. The values of $\alpha$ and $\beta$ currently adopted by various RC design codes (ACI, 2008; CEN, 2004; SNZ, 2006), which are dependent only on the concrete strength, are summarised in Table 1. The accuracy of these equivalent stress blocks in predicting the flexural strength of RC members can be studied by comparing the theoretical with the measured flexural strengths of RC beams and columns tested by other researchers. The comparison is shown in Table 2. From the table, it is evident that the equivalent rectangular concrete stress block can predict fairly accurately the strength of columns subjected to very high axial load levels, but underestimates the flexural strength of other columns and beams. The underestimation of strength is about $9 \%$ for beams and $19 \%$ for columns subjected to low to medium axial load levels. These phenomena should be dealt with cautiously because this will underestimate the shear demands of beams and columns in moment-resisting frame buildings, which will lead to premature shear failure (Arslan, 2010; Baczkowski and Kuang, 2008; Bukhari et al., 2010; Lu et al., 2009; Pam and Ho, 2001). The underestimation of maximum concrete strength developed in flexure will also overestimate the available ductility and rotational capacity of the lowest storey columns of a moment-resisting frame building (Arslan et al., 2010; Do Carmo and Lopes, 2006; Ho and Pam, 2010; Inel et al., 2007; Sebastian and Zhang, 2008; Shim et al., 2008; Wu et al., 2004). Then, plastic hinges cannot be formed (Bai and Au, 2008; Jaafar, 2008; Pam and Ho, 2009) and the desirable 'beam sidesway mechan-

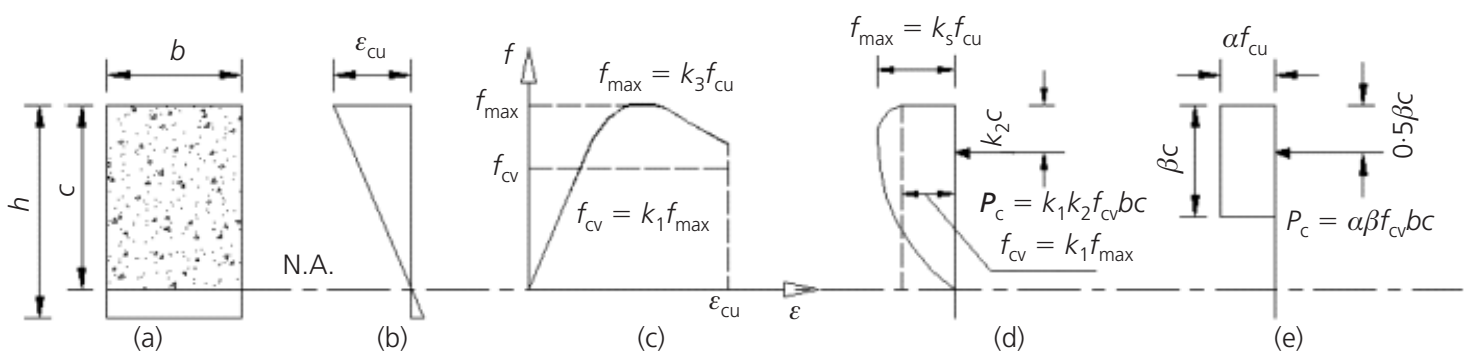

Figure 1. Concrete stress block parameters. (a) Cross-section.

(b) Strain distribution at ultimate state. (c) Stress-strain curve under flexure. (d) Actual stress distribution at ultimate state.

(e) Equivalent rectangular stress block 


Design
code $\quad \alpha \quad \beta$

$\begin{array}{lc}\text { ACI 318 } & 0.85 \text { for all } f_{c}^{\prime} \\ \text { (ACl, 2008) } & 0.85 \text { for } f_{c}^{\prime} \leqslant 50 \mathrm{MPa} \\ \text { Eurocode 2 } & \\ \text { (CEN, 2004) } & 0.85-0.85\left(\frac{f_{c}^{\prime}-50}{200}\right) \text { for } 50<f_{c}^{\prime} \leqslant 90 \mathrm{MPa} \\ \text { NZS 3101 } & 0.85 \text { for } 0<f_{c}^{\prime} \leqslant 55 \mathrm{MPa} \\ (\mathrm{SNZ}, 2006) & 0.85-0.004\left(f_{c}^{\prime}-55\right) \text { for } 55<f_{c}^{\prime} \leqslant 80 \mathrm{MPa} \\ & 0.75 \text { for } f_{c}^{\prime}>80 \mathrm{MPa}\end{array}$

Table 1. The values of equivalent concrete stress block parameters stipulated in RC design codes
0.85 for $f_{c}^{\prime} \leqslant 28 \mathrm{MPa}$

$0.85-0.007\left(f_{c}^{\prime}-28\right) \geqslant 0.65$ for $f_{c}^{\prime}>28 \mathrm{MPa}$

0.80 for $f_{c}^{\prime} \leqslant 50 \mathrm{MPa}$

$0.8-\left(\frac{f_{c}^{\prime}-50}{400}\right)$ for $50<f_{c}^{\prime} \leqslant 90 \mathrm{MPa}$

0.85 for $0<f_{c}^{\prime} \leqslant 30 \mathrm{MPa}$

$0.85-0.008\left(f_{c}^{\prime}-30\right)$ for $30<f_{c}^{\prime} \leqslant 55 \mathrm{MPa}$

0.65 for $f_{c}^{\prime}>55 \mathrm{MPa}$ ism' cannot be developed to allow moment redistribution (Oehlers et al., 2010; Spence, 2008; Zhou and Zheng, 2010) to occur during extreme events such as earthquake attack and accidental impact (Chen and May, 2009; Inel et al., 2008; Jones and Fraser, 2009) The consequence is that the columns would fail in a brittle manner without ample warning. For gravity-load-resisting structures, the overestimation of flexural strength will unnecessarily increase the member size and carbon content of the buildings, which reduces energy efficiency. Although the design of flexural ductility may be considered less important in a gravity-loadresisting structure, underestimation of flexural ductility will reduce the level of structural safety when it is subjected to extreme loads such as overloading, blasting and sudden impact.

From the comparison shown in Table 2, it is apparent that underestimation of flexural strength by the equivalent rectangular stress block of various design codes is different in beams and columns. Since the strain gradient in beams and columns is different at the ultimate state due to the presence of axial load, it is believed that the underestimation may be attributed to the effects of strain gradient. In fact, some researchers investigated the effects of strain gradient on the concrete stress-strain curve developed in flexure many years ago. Sturman et al. (1965) determined the stress-strain curve of normal-strength concrete (NSC) developed under concentric and eccentric loads and found that the maximum concrete stress that can be developed in eccentrically loaded columns was higher than that in concentrically loaded columns. Clark et al. (1967) reported that the maximum stress developed in NSC increases as strain gradient increases. Soliman and Yu (1967) derived the NSC stress-strain curve in flexure and pointed out that the maximum stress increased as the volume of transverse steel increased (i.e. as strain gradient increased). Smith and Orangun (1969) derived a fourth-order polynomial for the concrete stress-strain developed in flexure, which was significantly different from that of the uniaxial concrete compression curve. More recently, Tan and Nguyen (2004) derived stress-strain curves for NSC and high- strength concrete (HSC) (up to $76 \mathrm{MPa}$ ) in flexure based on experimental results and found that the maximum concrete stress developed in flexure is higher than that in uniaxial compression. This also agreed with the test results obtained by Yi et al. (2002) who reported that the maximum and equivalent concrete stresses decrease as column size increases (i.e. as strain gradient decreases). Tabsh (2006) also reported on the strain gradient effect in the HSC stress-strain curve developed under flexure.

In this work, the effects of strain gradient on the maximum concrete stress and equivalent rectangular concrete stress block developed in flexure were studied experimentally by testing 16 inverted T-shaped column specimens under concentric and eccentric axial loads, as well as horizontal load. The specimens were divided into six groups, each of which contained specimens with identical cross-section properties. In each group, one specimen was subjected to concentric load while the rest was/were subjected to eccentric or horizontal loads. To study the effects of strain gradient, the ratio of the maximum concrete compressive stress developed in the specimens subjected to eccentric/horizontal load to the maximum uniaxial compressive stress $\left(\sigma_{\max }\right)$ developed in the counterpart specimens subjected to concentric load (denoted by $k_{3}^{\prime}$ ) was determined based on axial force and moment equilibriums. Using the obtained value of $k_{3}^{\prime}$, the stress block parameters $k_{1}, k_{2}$ and $k_{3}$ and the equivalent concrete stress block parameters $\alpha$ and $\beta$ were determined. From the test results, it was found that the currently adopted values of $k_{3}$ and $\alpha$ are only applicable to RC members subjected to a small strain gradient. For a larger strain gradient, these parameters increased as strain gradient increased. On the other hand, $k_{1}, k_{2}$ and $\beta$ remained relatively constant irrespective of strain gradient. To facilitate practical flexural strength design of $\mathrm{RC}$ members, formulas correlating $k_{3}, \alpha$ and $\beta$ to the strain gradient are proposed. The applicability of these formulas is verified by comparing the theoretical flexural strength evaluated using the proposed formula with the measured strength of RC beams and columns obtained by other researchers. Lastly, the effects of strain gradient on the 


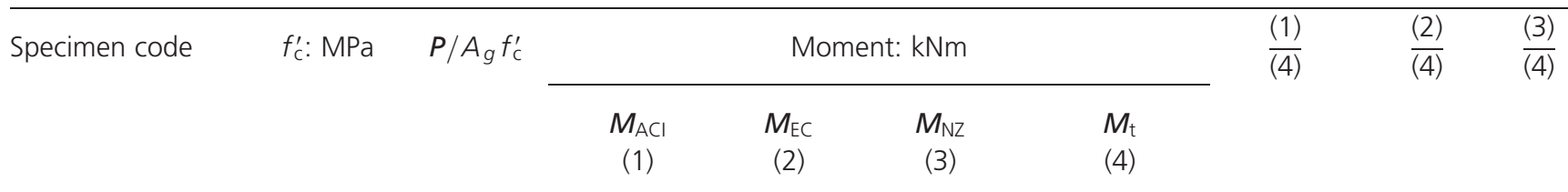

\section{Beams}

\begin{tabular}{|c|c|c|c|c|c|c|c|c|c|}
\hline$A^{a}$ & $41 \cdot 3$ & - & $97 \cdot 0$ & $97 \cdot 0$ & $97 \cdot 0$ & $104 \cdot 0$ & 0.93 & 0.93 & 0.93 \\
\hline $\mathrm{B}^{\mathrm{a}}$ & $41 \cdot 3$ & - & 45.0 & 45.0 & $45 \cdot 0$ & $49 \cdot 6$ & 0.91 & 0.91 & 0.91 \\
\hline$T 3^{b}$ & $27 \cdot 7$ & - & 28.9 & $29 \cdot 3$ & 28.9 & $32 \cdot 5$ & 0.89 & 0.90 & 0.89 \\
\hline$T 6^{b}$ & $27 \cdot 7$ & - & $170 \cdot 5$ & $171 \cdot 2$ & $170 \cdot 5$ & $192 \cdot 4$ & 0.89 & 0.89 & 0.89 \\
\hline
\end{tabular}

Columns subjected to low axial load level

\begin{tabular}{|c|c|c|c|c|c|c|c|c|c|}
\hline$C 1-1^{c}$ & 24.9 & 0.113 & $300 \cdot 5$ & $305 \cdot 1$ & $300 \cdot 5$ & $351 \cdot 4$ & 0.86 & 0.87 & 0.86 \\
\hline$C 1-2^{c}$ & $26 \cdot 7$ & 0.106 & $303 \cdot 8$ & $308 \cdot 2$ & $303 \cdot 8$ & 374.6 & 0.81 & 0.82 & 0.81 \\
\hline$C 2-2^{c}$ & $27 \cdot 1$ & 0.156 & $325 \cdot 2$ & $330 \cdot 5$ & $325 \cdot 2$ & 399.9 & 0.81 & 0.83 & 0.81 \\
\hline
\end{tabular}

Columns subjected to medium axial load level

\begin{tabular}{|c|c|c|c|c|c|c|c|c|c|}
\hline$\left(3-3^{c}\right.$ & $26 \cdot 9$ & 0.209 & 335.4 & $345 \cdot 9$ & 335.4 & $423 \cdot 8$ & 0.79 & 0.82 & 0.79 \\
\hline$x 6^{d}$ & 31.9 & 0.450 & $28 \cdot 5$ & $29 \cdot 0$ & $28 \cdot 6$ & $37 \cdot 1$ & 0.77 & 0.78 & 0.77 \\
\hline$x 7^{d}$ & $35 \cdot 7$ & 0.450 & $29 \cdot 7$ & $30 \cdot 5$ & $29 \cdot 8$ & $37 \cdot 1$ & 0.80 & 0.82 & 0.80 \\
\hline $\mathrm{SBCM}-\mathrm{8}^{\mathrm{e}}$ & $28 \cdot 0$ & 0.220 & $46 \cdot 0$ & $46 \cdot 0$ & $46 \cdot 0$ & $58 \cdot 7$ & 0.78 & 0.78 & 0.78 \\
\hline
\end{tabular}

Columns subjected to high axial load level

\begin{tabular}{lllllllll}
\hline A-16 \\
E-2
\end{tabular}

apecce and Fabbrocino (1999)

${ }^{b}$ Debernardi and Taliano (2002)

'Mo and Wang (2000)

'Lam et al. (2003)

eMarefat et al. (2005)

fSheikh and Yeh (1990)

Table 2. Comparison of flexural strengths obtained from codes and previous tests

maximum concrete stress developed in flexure will be explained using the previous test observations on the progressive development of concrete micro-cracking in pure axially loaded and flexural NSC columns obtained by Sturman et al. (1965).

\section{Test programme}

2.1 Experimental setup and details of specimens Sixteen inverted T-shaped square column specimens with concrete cube strength ranging from 32 to $58 \mathrm{MPa}$ were fabricated and 
tested under concentric and eccentric axial loads or horizontal loads. They were divided into six groups, with each group comprising specimens with identical cross-section and material strength properties. Concrete for the same group of specimens was cast from the same batch of concrete transported by the same truck from the same plant. They were also cured under the same environmental conditions and thus the concrete strength for all specimens within the same group can be regarded as identical. One of the specimens in each group was tested under concentric load, while the rest were tested under eccentric axial load (for small strain gradient) or horizontal load (for large strain gradient). The specimens had a cross-section of $400 \times 400 \mathrm{~mm}^{2}$. The height of the columns was $1400 \mathrm{~mm}$ and the length of the supporting beams $1500 \mathrm{~mm}$, as shown in Figure 2. For specimens

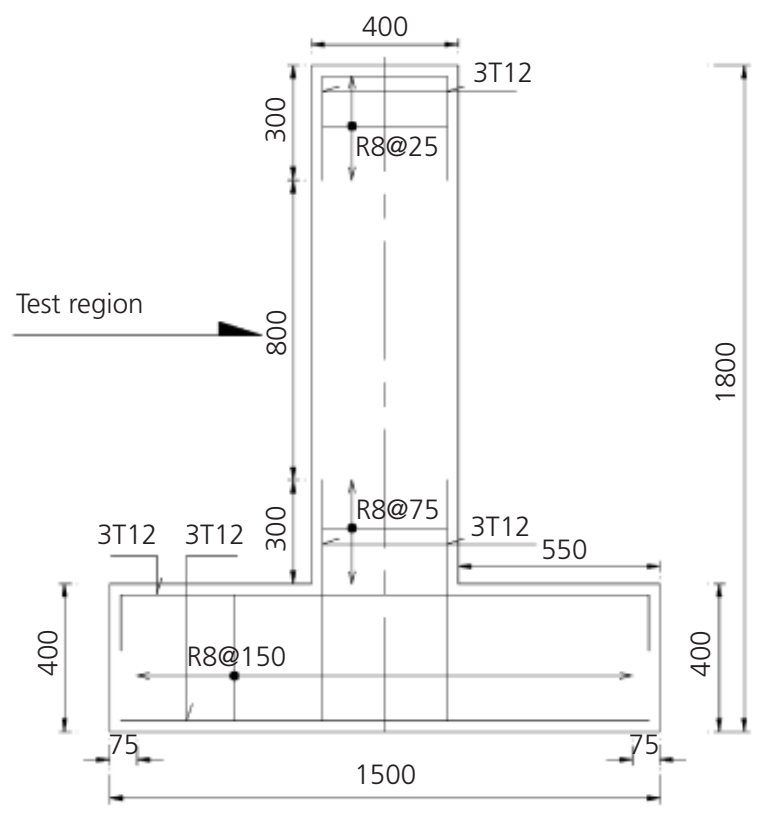

(a)

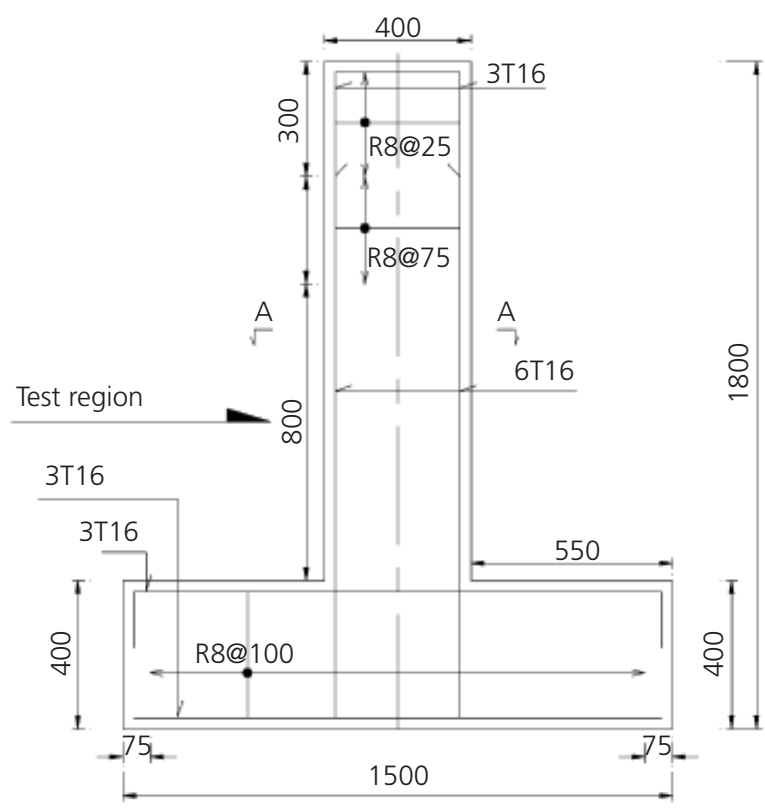

(c)

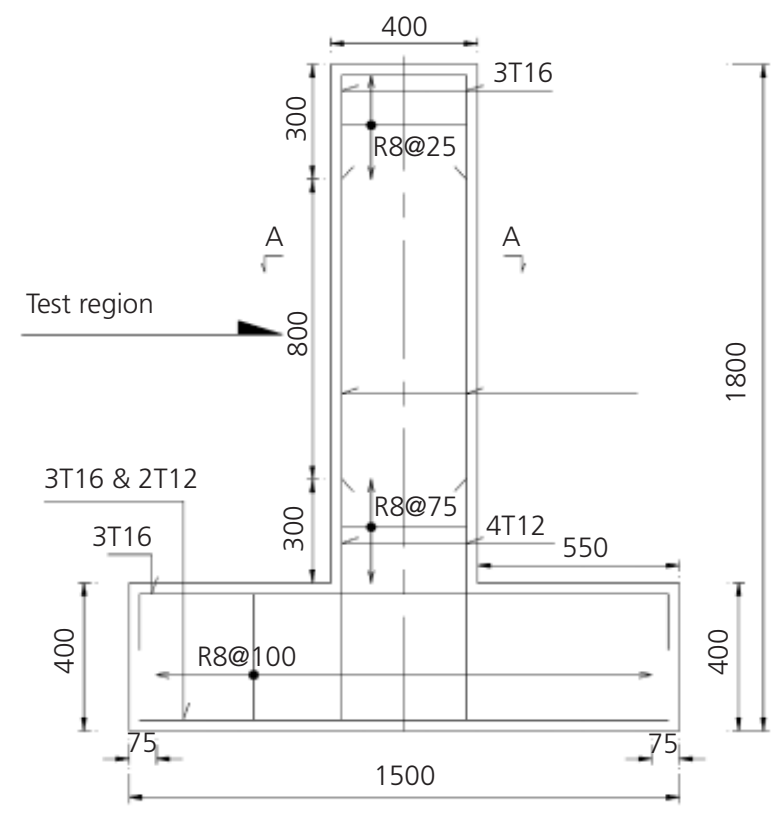

(b)

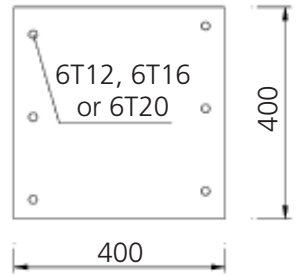

A-A

Figure 2. (a) PC specimen. (b) Eccentrically loaded RC specimen.

(c) Horizontally loaded RC specimen. Dimensions in $\mathrm{mm}$ 
tested under concentric and eccentric axial loads, the testing regions were in the middle $800 \mathrm{~mm}$ of the column height. For specimens tested under horizontal load, the testing regions were within $800 \mathrm{~mm}$ from the beam-column interface. Outside the testing regions, the columns were heavily confined with transverse steel and/or square hollow steel tube $\left(400 \times 400 \mathrm{~mm}^{2}\right)$ so that failure would always take place in the pre-determined testing regions. The plain concrete (PC) specimens did not contain any longitudinal steel within the testing region, while RC specimens contained different amounts of longitudinal steel with steel ratios of $0.42-1 \cdot 18 \%$. The cross-section properties and material strengths of each test specimen are listed in Table 3; the values are those commonly adopted by other researchers (Ahn and Shin, 2007; Choi et al., 2009; Han et al., 2010; Kim et al., 2007; Sim et al., 2009; Supaviriyakit et al., 2007; Xiao et al., 2008). The specimens were coded as follows. The first number refers to the concrete cube strength on day 28 and the second number refers to the percentage longitudinal steel ratio.

The uniaxial concrete stress-strain behaviour in each group of specimens was obtained by testing one of the specimens under concentric axial load. For RC specimens, the concrete stress was obtained by subtracting the steel force from the total applied load and then the difference was divided by the concrete area. The strain was obtained by dividing axial shortening of the specimen (measured with linear variable displacement transducer (LVDTs)) by its gauge length. The concrete stress-strain curve developed in flexure (with strain gradient) was obtained by modifying the obtained uniaxial concrete stress-strain curve such that the theoretical axial force and moment matched the experimentally measured values. For the specimens tested under eccentric loading, different eccentricities (ranging from 50 to $140 \mathrm{~mm}$ as summarised in Table 3) were used to simulate different extents of strain gradient in columns at ultimate state. Nevertheless, since the maximum eccentricity, which is restricted by the column size, was about $150 \mathrm{~mm}$, specimens that needed to be tested under larger eccentricities to simulate the effects of large strain gradient were tested under simultaneous axial and horizontal loads.

The test setup for the three types of loading is shown in Figure 3. The axial and horizontal loads applied to the columns were produced by a computerised electro-hydraulic servo controlled multi-purpose testing machine having a maximum loading capacities of 10000 and $1500 \mathrm{kN}$, respectively.

Because of the different loading arrangements, the failure modes of the specimens were different. When a column was subjected to concentric load or small eccentricity, it would fail in compression where the tension steel would not yield. However, when a column was subjected to large eccentricity or simultaneous axial and horizontal loads, it would fail in tension where the tension steel would yield. These failure modes are represented by different locations on the interaction curve of the column specimens (Figure 4).

\subsection{Instrumentation}

Instrumentation to monitor the behaviour of the column specimens included strain gauges and LVDTs (Figure 5)

\begin{tabular}{|c|c|c|c|c|c|c|c|c|c|}
\hline \multirow[t]{2}{*}{ Group } & \multirow[t]{2}{*}{ Specimen code } & \multirow{2}{*}{$\begin{array}{l}\text { Loading } \\
\text { mode }\end{array}$} & \multicolumn{4}{|c|}{ Longitudinal steel } & \multicolumn{2}{|c|}{$f_{\mathrm{cu}}: \mathrm{MPa}$} & \multirow[t]{2}{*}{ Eccentricity: mm } \\
\hline & & & $\rho_{\mathrm{s}}: \%$ & Detail & $f_{\mathrm{y}}: \mathrm{MPa}$ & $E_{\mathrm{s}}: \mathrm{GPa}$ & Day 28 & $\begin{array}{c}\text { Testing } \\
\text { day }\end{array}$ & \\
\hline \multirow[t]{2}{*}{1} & PC35-0-CON & Concentric & 0 & - & - & - & $35 \cdot 0$ & $35 \cdot 0$ & 0 \\
\hline & PC35-0-ECC & Eccentric & 0 & - & - & - & & $35 \cdot 3$ & 120 \\
\hline \multirow[t]{2}{*}{2} & RC30-0.42-CON & Concentric & 0.42 & 6T12 & 538 & 203 & $30 \cdot 0$ & $35 \cdot 9$ & 0 \\
\hline & RC30-0.42-ECC & Eccentric & & & & & & $35 \cdot 9$ & 140 \\
\hline \multirow[t]{2}{*}{3} & RC28-0.75-CON & Concentric & 0.75 & 6T16 & 533 & 203 & $28 \cdot 2$ & $33 \cdot 6$ & 0 \\
\hline & RC28-0.75-ECC & Eccentric & & & & & & $31 \cdot 6$ & 140 \\
\hline \multirow[t]{2}{*}{4} & RC38-1.18-CON & Concentric & $1 \cdot 18$ & $6 \mathrm{~T} 20$ & 536 & 200 & $38 \cdot 4$ & $43 \cdot 2$ & 0 \\
\hline & RC38-1·18-ECC & Eccentric & & & & & & $42 \cdot 8$ & 110 \\
\hline \multirow[t]{3}{*}{5} & RC50-0.75-CON & Concentric & 0.75 & 6Т16 & 515 & 203 & $50 \cdot 3$ & $50 \cdot 3$ & 0 \\
\hline & RC50-0.75-ECC-1 & Eccentric & & & & & & $58 \cdot 2$ & 120 \\
\hline & RC50-0.75-ECC-2 & Eccentric & & & & & & $58 \cdot 2$ & 140 \\
\hline \multirow[t]{5}{*}{6} & RC41-0.75-CON & Concentric & 0.75 & $6 \mathrm{~T} 16$ & 498 & 198 & $40 \cdot 6$ & $42 \cdot 1$ & 0 \\
\hline & RC41-0.75-ECC-1 & Eccentric & & & & & & $49 \cdot 1$ & 50 \\
\hline & RC41-0.75-ECC-2 & Eccentric & & & & & & $49 \cdot 1$ & 130 \\
\hline & RC41-0.75-HOR-1 & Horizontal & & & & & & $46 \cdot 4$ & - \\
\hline & RC41-0.75-HOR-2 & Horizontal & & & & & & $46 \cdot 4$ & - \\
\hline
\end{tabular}




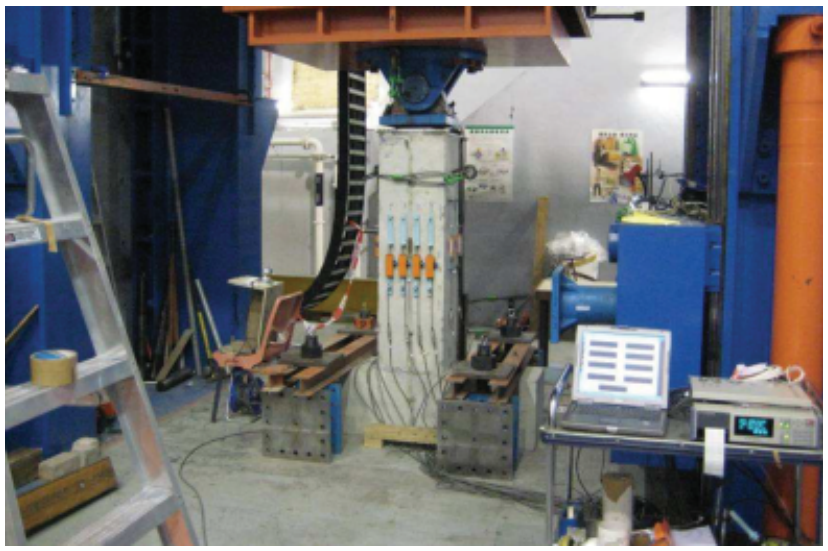

(a)

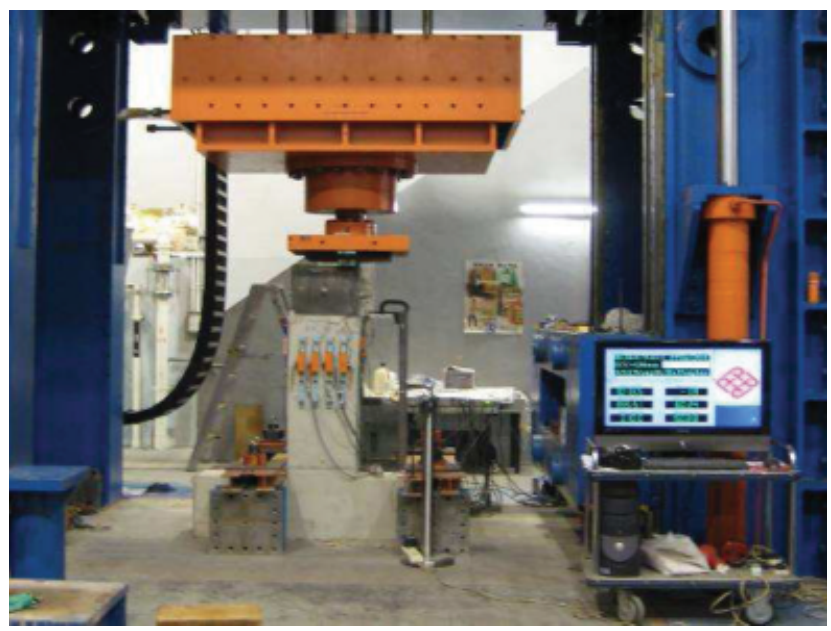

(b)

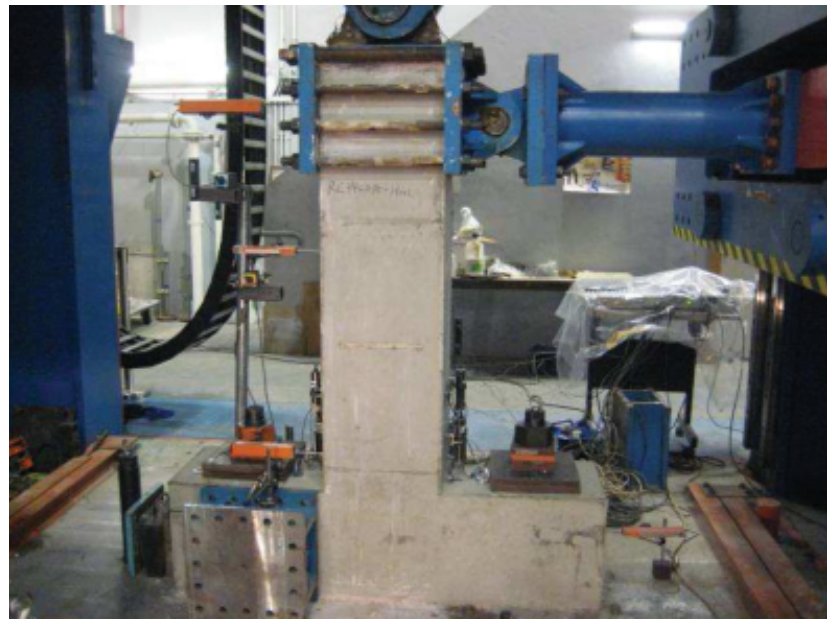

(c)

Figure 3. Loading setup: (a) concentric loading; (b) eccentric loading; (c) horizontal and axial loading (a) Strain gauges were adopted for both steel and concrete. The steel strain gauges were attached to the longitudinal steel bars located within the testing region. The concrete strain gauge(s) was/were attached on each face of every concentric and eccentric specimen. For the horizontally loaded specimens, concrete strain gauges were attached on the extreme tension and compression column faces.

(b) For specimens subjected to concentric and eccentric loads, a total of 12 LVDTs were installed on four sides of the specimen within the test area to measure the deformation due to axial load and/or bending moment. For specimens subjected to horizontal load, three LVDTs were installed on each of the extreme tension and compression column faces.

\subsection{Testing procedure}

For specimens subjected to concentric and eccentric loads, vertical load application was set in a displacement-controlled manner at a rate of $0.36 \mathrm{~mm} / \mathrm{min}$. For horizontally loaded specimens, the prescribed axial load was applied first. Horizontal load was then applied in a displacement-controlled manner at a rate of $0.5 \mathrm{~mm} / \mathrm{min}$. Load application was stopped after the applied load had reached the maximum value and then dropped below $80 \%$ of the maximum value.

\section{Experimental results}

\subsection{Concentric specimens}

Example of specimens tested under concentric, eccentric and horizontal loads after failure are shown in Figures 6(a), 6(b) and 6(c) respectively. The measured concrete compressive forces of the concentrically loaded column specimens are plotted against their corresponding axial displacements in Figure 7. The total concrete compressive force is taken as the total compressive axial load applied by the actuator for PC specimens, while that of RC specimens was obtained by subtracting the compressive forces in longitudinal steels from the applied axial loads. All steel reinforcements adopted in the test were hot-rolled high-yield deformed bars of characteristic yield strength of not less than $460 \mathrm{MPa}$. For this type of steel, it has been commonly accepted for decades that a linearly elastic-perfectly plastic stress-strain curve can be used to describe the uniaxial stress-strain behaviour. The same stress-strain curve will be adopted for the steel reinforcement used in this study to determine the steel stress from the corresponding strain measured in the test by the strain gauges. The concrete stress-strain curves for all concentrically loaded specimens are also shown in Figure 7 ; these will be used to determine the maximum concrete compressive stress that can be developed in the counterpart eccentrically/horizontally loaded specimens. The strains of concrete were obtained by dividing the LVDT readings with the gauge length; they show good agreement with the strains measured by the concrete strain gauges (Figure 8). From Figure 7, it is evident that the concrete compressive force-displacement and stress-strain curves are fairly linear up to about $50 \%$ of the maximum force (stress). After this, the displacement (strain) increases more rapidly than the concrete 


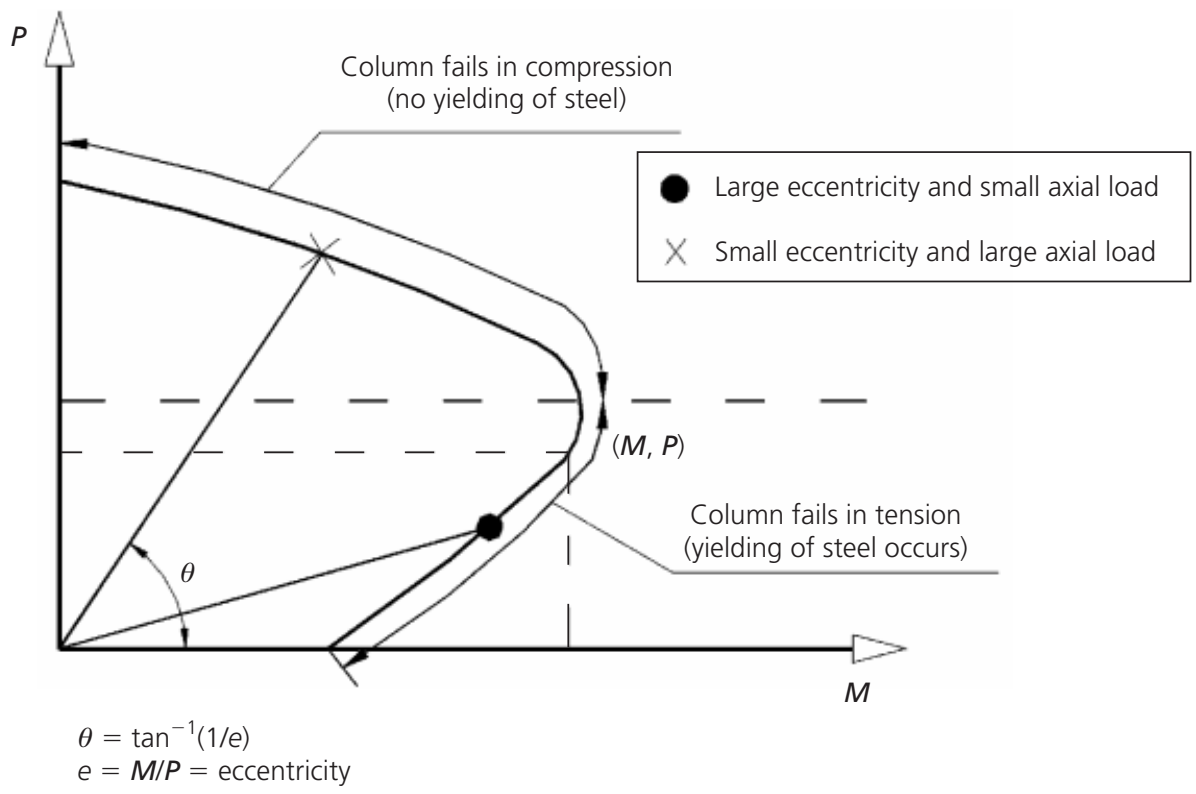

Figure 4. Failure modes and column interaction

compressive force (stress) due to the rapid degradation of column stiffness.

\subsection{Eccentric/horizontal specimens}

The measured concrete compressive forces of the eccentrically loaded specimens are plotted against actuator-measured vertical displacements of the column in Figure 9(a). Similarly, the concrete compressive forces of the $\mathrm{RC}$ specimens were obtained by subtracting the steel forces from the respective total applied loads. For the specimens tested under horizontal load, the measured horizontal load is plotted against its lateral drift in Figure 9(b). The maximum moment acting on the eccentrically loaded specimens was evaluated by multiplying the applied axial load by the eccentricity; for horizontally loaded specimens, the moment was obtained by multiplying the horizontal load by the lever arm (i.e. the vertical distance from the horizontal actuator to the beam-column interface). With the obtained maximum axial loads and moments, the concrete stress distribution developed in the eccentrically and horizontally loaded specimens with strain gradient effect can be investigated.

\section{Derivation of concrete stress block parameters}

4.1 Derivation of stress block parameters $k_{1}, k_{2}$ and $k_{3}$ The ratio of the maximum concrete stress developed in flexure to the concrete cube strength, $k_{3}$, will be determined by equating the theoretical axial force and moment with the measured values of the eccentrically or horizontally loaded specimens. The theoretical values can be computed based on the stress-strain curve obtained from the concentrically loaded specimens multiplied by $k_{3}^{\prime}$, which is defined as the ratio of the maximum concrete stress developed in eccentrically or horizontally loaded specimens to its uniaxial strength in concentrically loaded columns, to take into account the effects of strain gradient. Firstly, the uniaxial concrete stress-strain curve of each concentrically loaded specimen was obtained by fitting the measured stress and strain data using the parabolic function

1. $\sigma=A \varepsilon^{2}+B \varepsilon$

where $\sigma$ and $\varepsilon$ are the concrete stress and strain developed in concentrically loaded specimens, respectively, and $A$ and $B$ are coefficients obtained from regression analysis. From the definition of $k_{3}^{\prime}$, the concrete stress-strain curve developed in eccentrically or horizontally loaded specimens with strain gradient effect can be obtained by multiplying both sides of Equation 1 by $k_{3}^{\prime}$

$$
\text { 2. } k_{3}^{\prime} \sigma=k_{3}^{\prime}\left(A \varepsilon^{2}+B \varepsilon\right)
$$

where $k_{3}^{\prime} \sigma$ is the concrete stress developed in flexure. The value of $k_{3}^{\prime}$ and $c$ for each eccentrically or horizontally loaded specimen can be determined by considering the axial force $(\boldsymbol{P})$ and moment ( $\boldsymbol{M})$ equilibriums of the eccentrically or horizontally loaded column section, as expressed by Equations $3 \mathrm{a}$ and $3 \mathrm{~b}$, respectively (compression is taken as positive). Finally, the value of $k_{3}$ can be determined using Equation $3 \mathrm{~d}$. 
Structures and Buildings

Volume 165 Issue SB10
Strain gradient effects on concrete

stress-strain curve

Peng and $\mathrm{Ho}$

\section{LVDT rods}

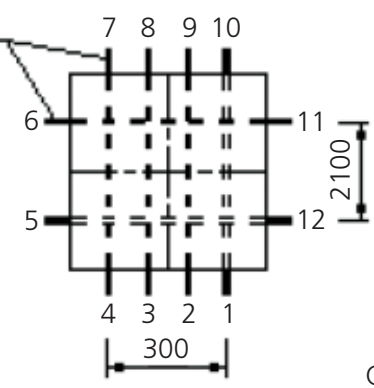

Concentric
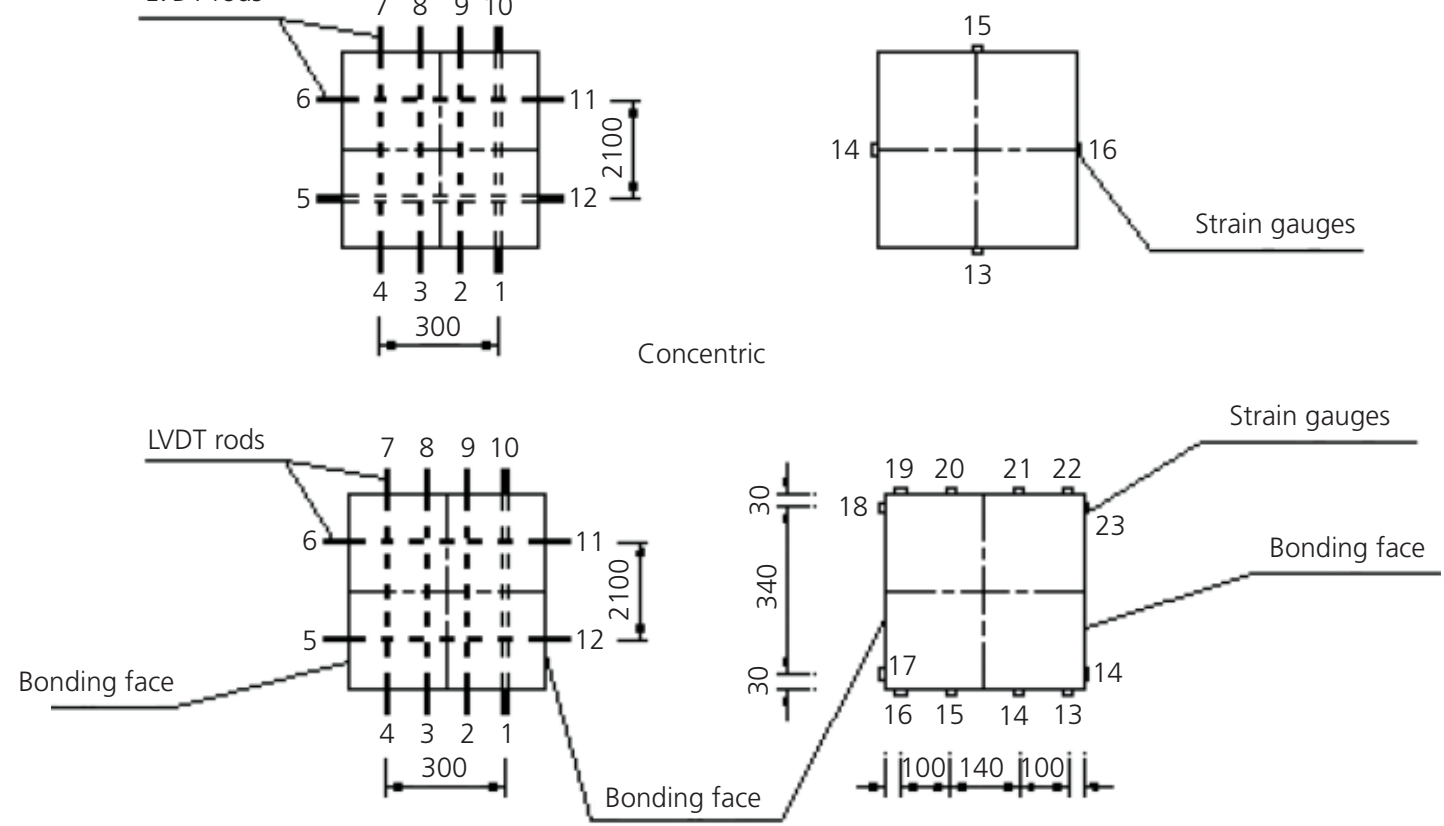

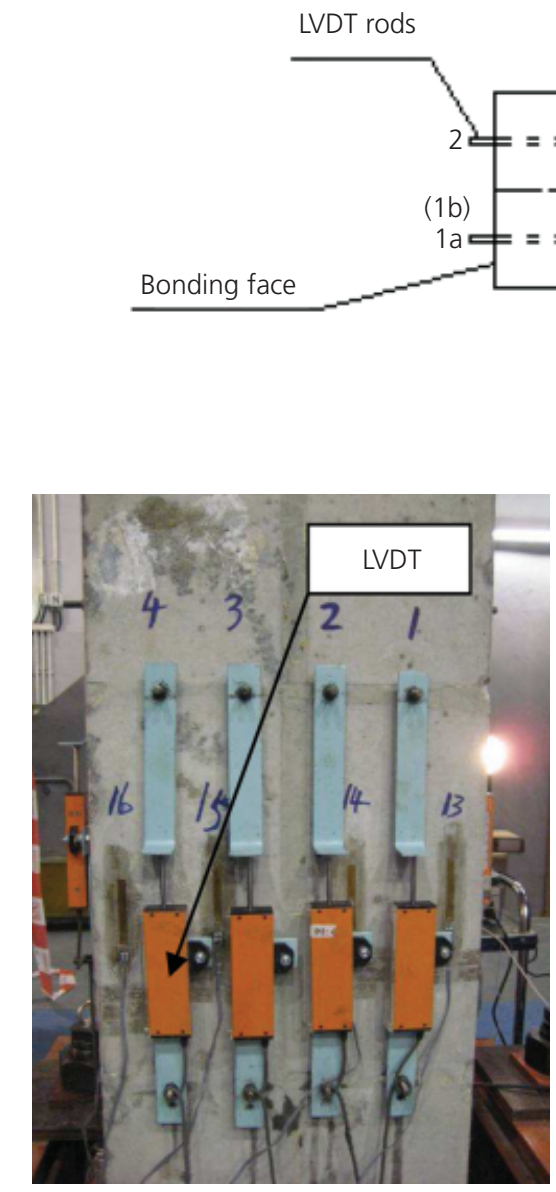

LVDT (eccentric)
Eccentric

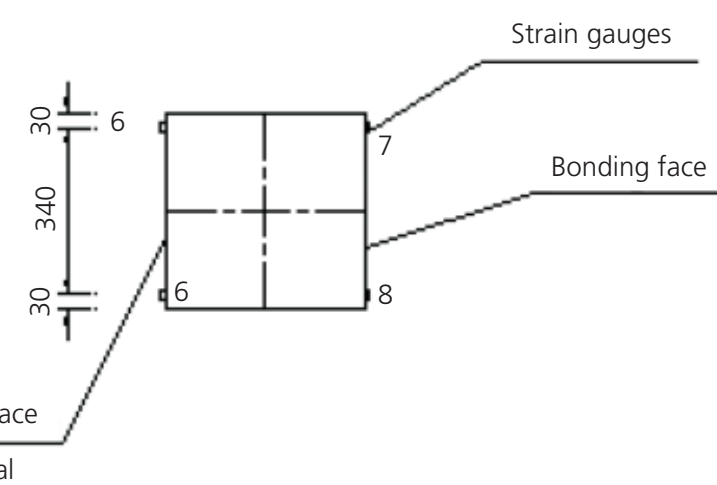

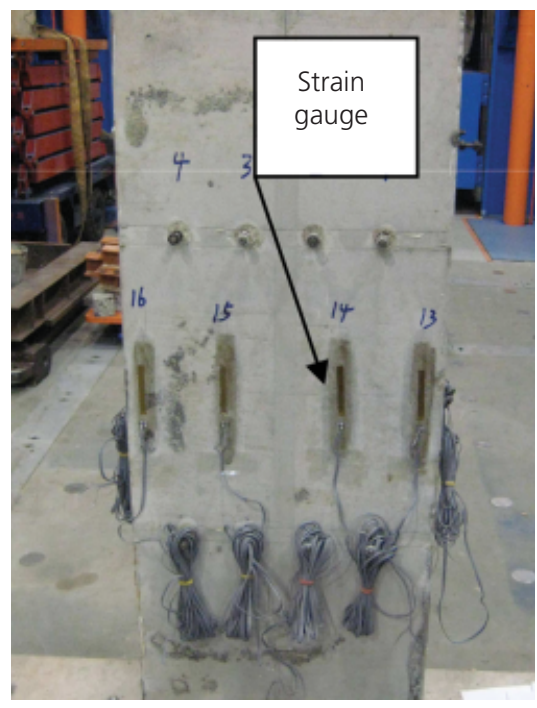

Strain gauge (eccentric)

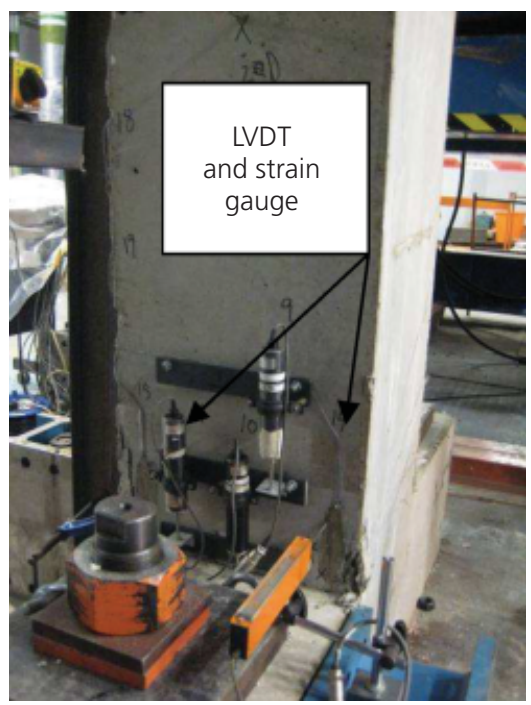

LVDT \& strain gauge (horizontal) 


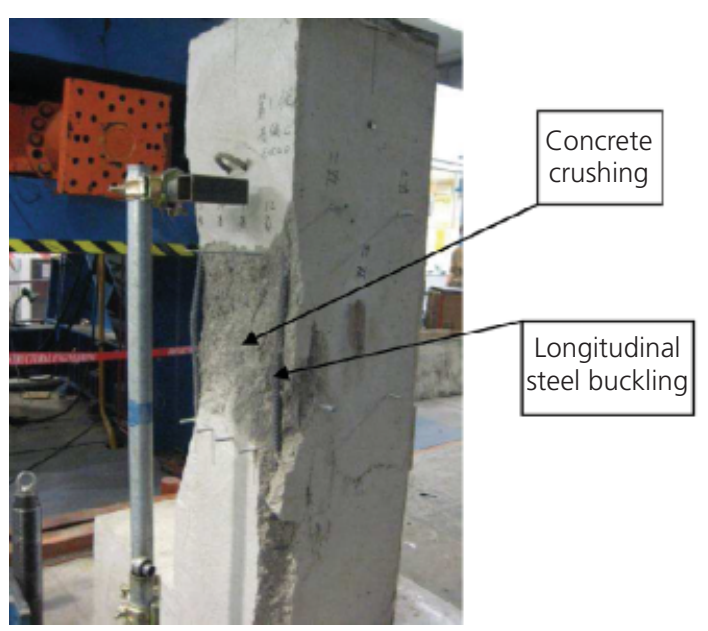

(a)

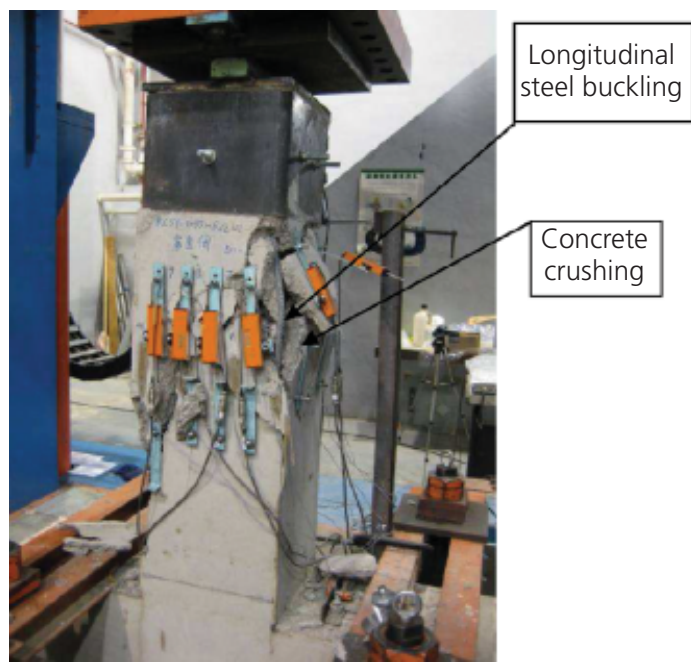

(b)

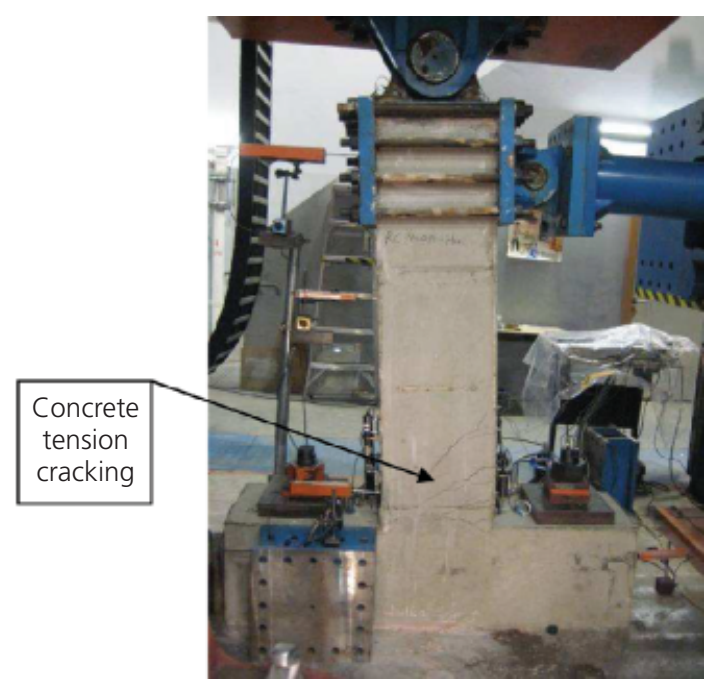

(c)

Figure 6. Selected specimens after failure: (a) RC41-0.75-CON; (b) RC41-0.75-ECC-1; (c) RC41-0.75-HOR-1 3a. $\quad \boldsymbol{P}=\int_{A_{\mathrm{c}}} k_{3}\left(A \varepsilon^{2}+B \varepsilon\right) \mathrm{d} A_{\mathrm{c}}+\sum_{i=1}^{n} f_{\mathrm{si}} A_{\mathrm{s} i}$

$$
\begin{aligned}
\boldsymbol{M}= & \int_{A_{\mathrm{c}}} k_{3}\left(A \varepsilon^{2}+B \varepsilon\right)\left(\frac{h}{2}-c+x\right) \mathrm{d} A_{\mathrm{c}} \\
& +\sum_{i=1}^{n} f_{\mathrm{s} i} A_{\mathrm{s} i}\left(\frac{h}{2}-d_{i}\right)
\end{aligned}
$$

3c. $\varepsilon=(x / c) \varepsilon_{\mathrm{cu}}$

3d. $k_{3}=k_{3}^{\prime}\left(\sigma_{\max } / f_{\mathrm{cu}}\right)$

where $A_{\mathrm{c}}$ is the area of concrete compression zone, $x$ is the distance of strip $\mathrm{d} A_{\mathrm{c}}$ from the neutral axis, $n$ is the total number of steel bars, $f_{\mathrm{s} i}$ and $A_{\mathrm{s} i}$ are, respectively, the stress and area of the $i$ th steel bar, $d_{i}$ is the distance of the $i$ th steel bar from the extreme concrete compressive fibre, $\varepsilon_{\mathrm{cu}}$ is the ultimate concrete strain, $f_{\text {cu }}$ is the compressive concrete cube strength and $\sigma_{\max }$ is the maximum uniaxial concrete stress obtained from concentrically loaded specimens. The contribution of concrete tensile stress to the bending moment capacity is neglected because either the tensile stress of concrete is very small in eccentrically loaded columns or the lever arm from the neutral axis is very small in horizontally loaded columns.

Based on the values of $k_{3}$ and $c$ obtained from Equation 3, $k_{1}$ and $k_{2}$ can be determined from Equations $4 \mathrm{a}$ and $4 \mathrm{~b}$, respectively

4a. $\quad \boldsymbol{P}=k_{1} k_{3} f_{\mathrm{cu}} b c+\sum_{i=1}^{n} f_{\mathrm{si}} A_{\mathrm{s} i}$

$4 b$.

$$
\boldsymbol{M}=k_{1} k_{3} f_{\mathrm{cu}} b c\left(\frac{h}{2}-k_{2} c\right)+\sum_{i=1}^{n} f_{\mathrm{s} i} A_{\mathrm{s} i}\left(\frac{h}{2}-d_{i}\right)
$$

The obtained values of $k_{1}, k_{2}, k_{3}$ and $c$ of the eccentrically and horizontally loaded specimens are listed in Table 4 together with their corresponding $\sigma_{\max }$, ultimate concrete strain $\varepsilon_{\mathrm{cu}}$ and strain gradient $\phi=\varepsilon_{\mathrm{cu}} / c$ (in $\left.\mathrm{rad} / \mathrm{m}\right)$. It is evident from the table that

(a) the value of $k_{3}$ and the product $k_{1} \mathrm{k}_{3}$ increase as $\phi$ increases, which verifies the fact that the strain gradient can improve the maximum concrete stress and concrete force developed in $\mathrm{RC}$ members under flexure 


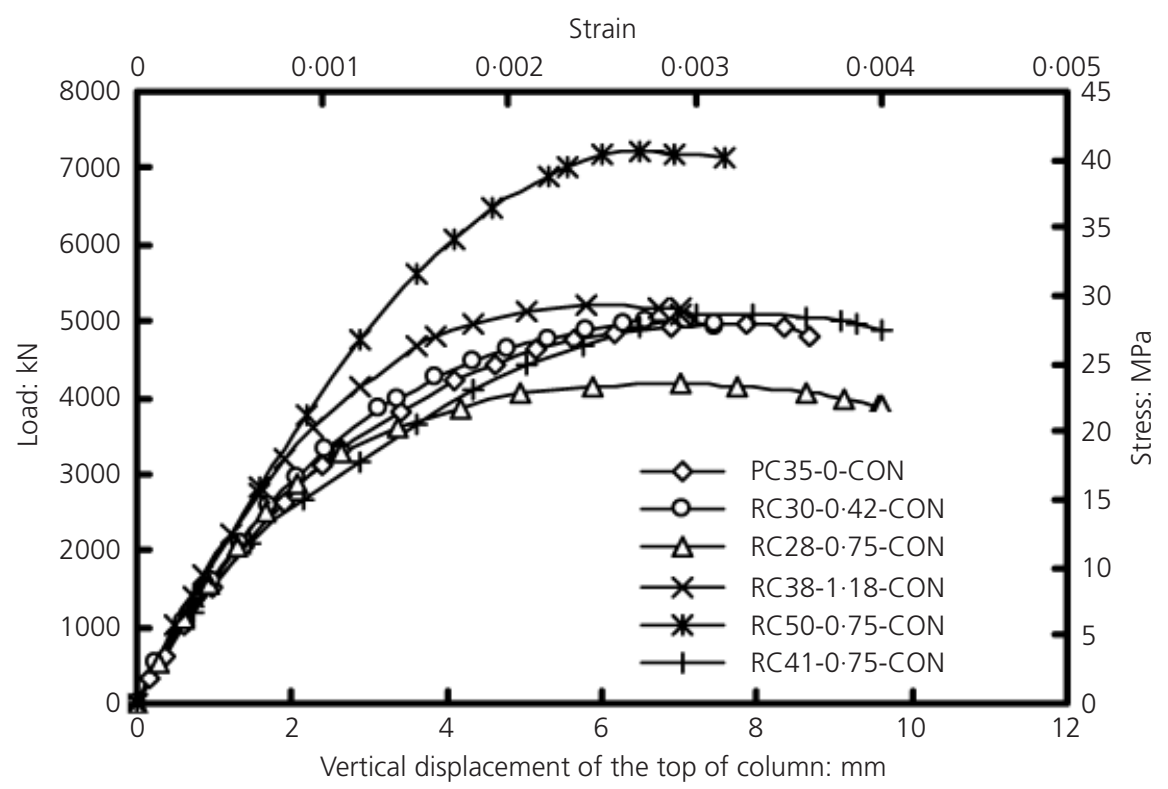

Figure 7. Load-displacement and stress-strain curves of concentrically loaded specimens

(b) the values of $k_{2}$ are not sensitive to variations in strain gradient.

The obtained values of $k_{1}, k_{2}$ and $k_{3}$ obtained from Equations 3 and 4 were averaged and are compared with values obtained by other researchers in Table 5 (Hognestad et al., 1955; Kaar et al., 1978; Mansur et al., 1997; Swartz et al., 1985; Tan and Nguyen, 2004, 2005). The values of $k_{1}$ and $k_{2}$ obtained in this study agree closely with those obtained by others. However, the values of $k_{3}$ and the product $k_{1} \mathrm{k}_{3}$ are larger than those obtained in other works. This indicates that the maximum concrete compressive stress and concrete force that can be developed in RC members subjected to flexure with or without axial load should be larger and dependent on strain gradient.

\subsection{Derivation of equivalent rectangular stress block parameters $\alpha$ and $\beta$}

The values of $\alpha$ and $\beta$ of the equivalent rectangular concrete stress block can be evaluated using Equations $5 \mathrm{a}$ and $5 \mathrm{~b}$ by considering the axial load and moment equilibria in Figure 1(e). The value of $\alpha$ for concentrically loaded specimens can be evaluated using Equation $5 \mathrm{c}$ by considering an equivalent concrete stress, $\alpha f_{\text {cu }}$, acting over the concrete cross-section. For eccentric loading

$5 a$.

$$
\boldsymbol{P}=\alpha \beta f_{\mathrm{cu}} b c+\sum_{i=1}^{n} f_{\mathrm{si}} A_{\mathrm{s} i}
$$

5b. $\quad \boldsymbol{M}=\alpha \beta f_{\mathrm{cu}} b c\left(\frac{h}{2}-\frac{\beta c}{2}\right)+\sum_{i=1}^{n} f_{\mathrm{s} i} A_{\mathrm{s} i}\left(\frac{h}{2}-d_{i}\right)$

and for concentric loading

5c. $\quad \boldsymbol{P}=\alpha f_{\mathrm{cu}} A_{\mathrm{c}}+\sum_{i=1}^{n} f_{\mathrm{si}} A_{\mathrm{s} i}$

Table 6 lists the obtained values of $\alpha$ and $\beta$, together with the respective strain gradients $\phi$ for all specimens. The following conclusion may be drawn from the obtained results.

(a) The average value of $\alpha$ obtained from the concentrically loaded columns is about $0 \cdot 71$, which is very close to the design value of $\alpha=0.67$ stipulated in Eurocode 2 (CEN, 2004) (assuming $f_{\mathrm{c}}^{\prime}=0 \cdot 8 f_{\mathrm{cu}}$ )

(b) The values of $\alpha$ for specimens subjected to a strain gradient are all larger than $0 \cdot 67$. This implies that strain gradient can enhance the equivalent concrete stress of RC members developed in flexure.

(c) The values of $\alpha$ for the eccentrically and horizontally loaded specimens remain fairly constant at low strain gradient, but increase with moderate strain gradient until reaching a maximum limit of about $\alpha \approx 1 \cdot 15$.

It is evident from the above that the variation of $\alpha$ with strain gradient is not linear and is dependent on the value of the strain 


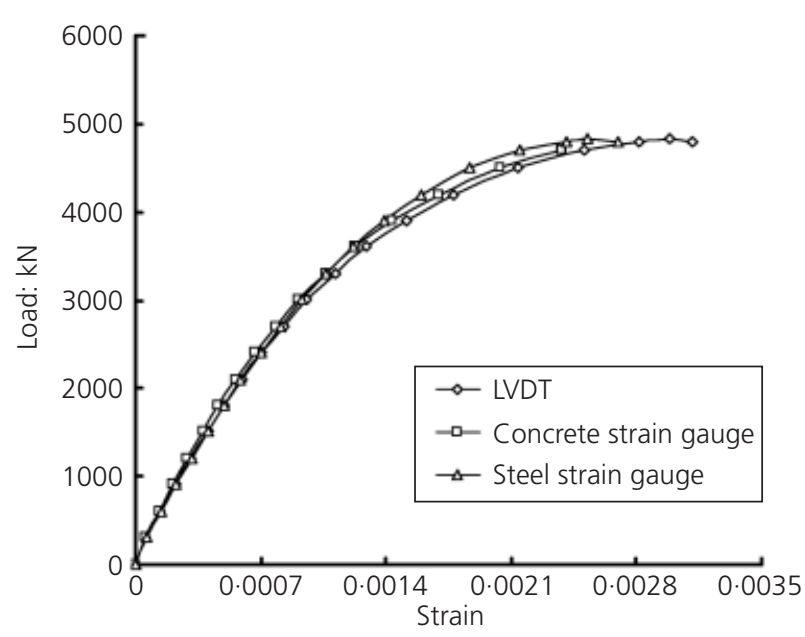

(a)

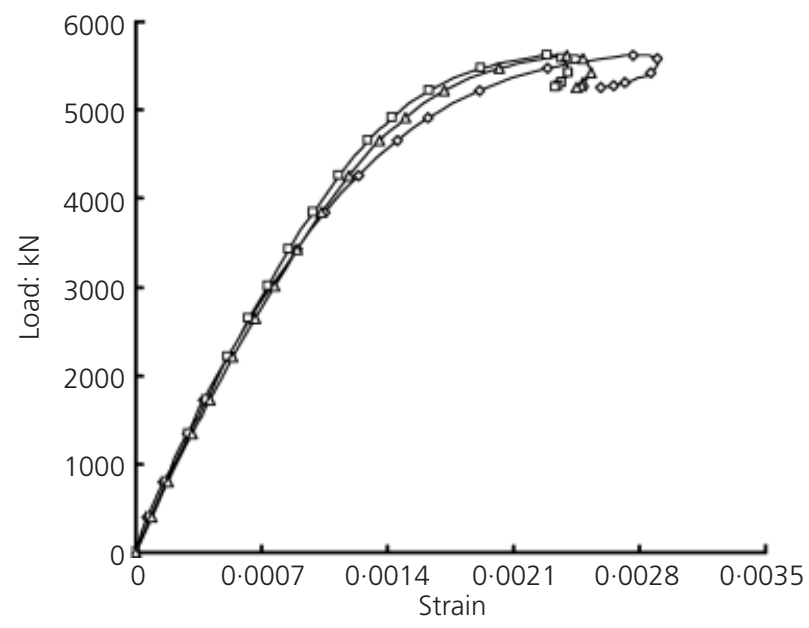

(c)

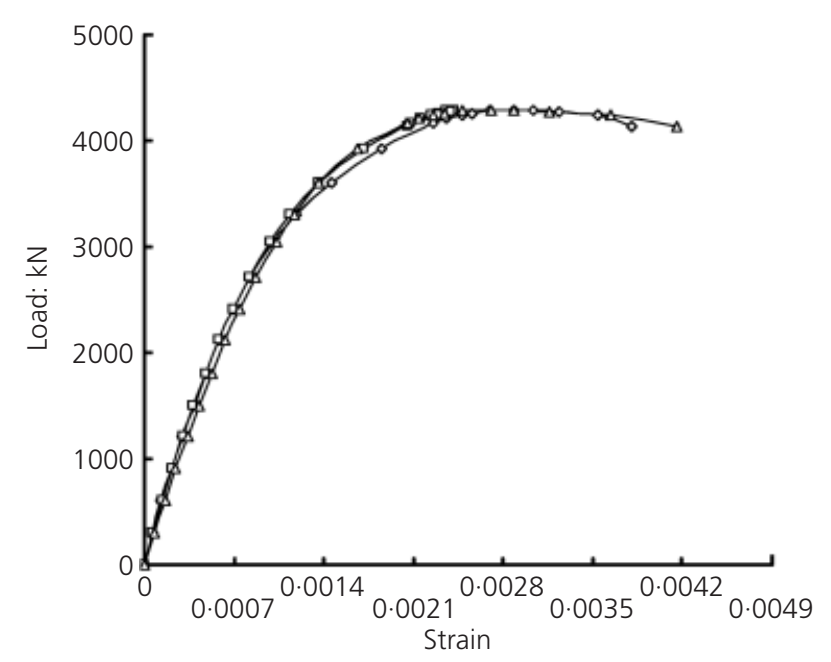

(b)

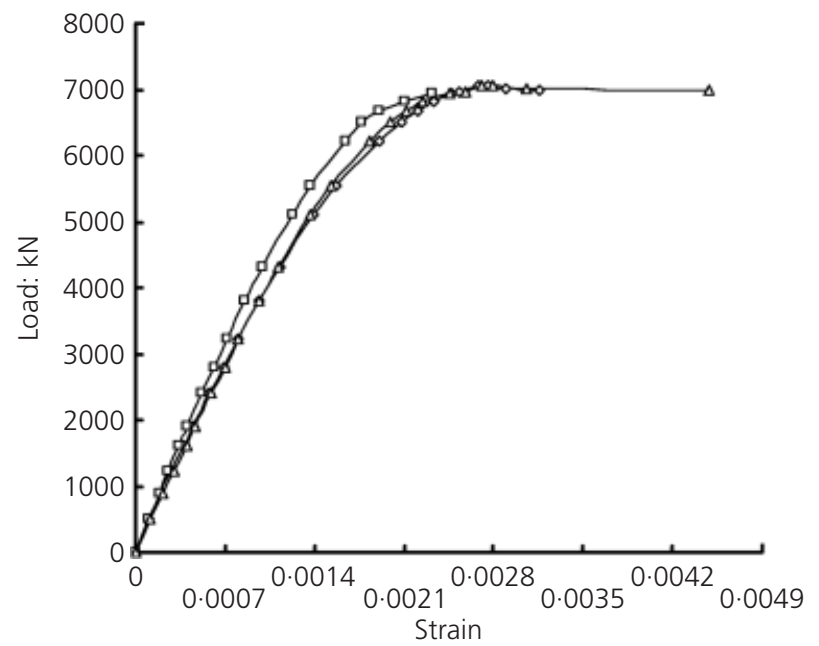

(d)

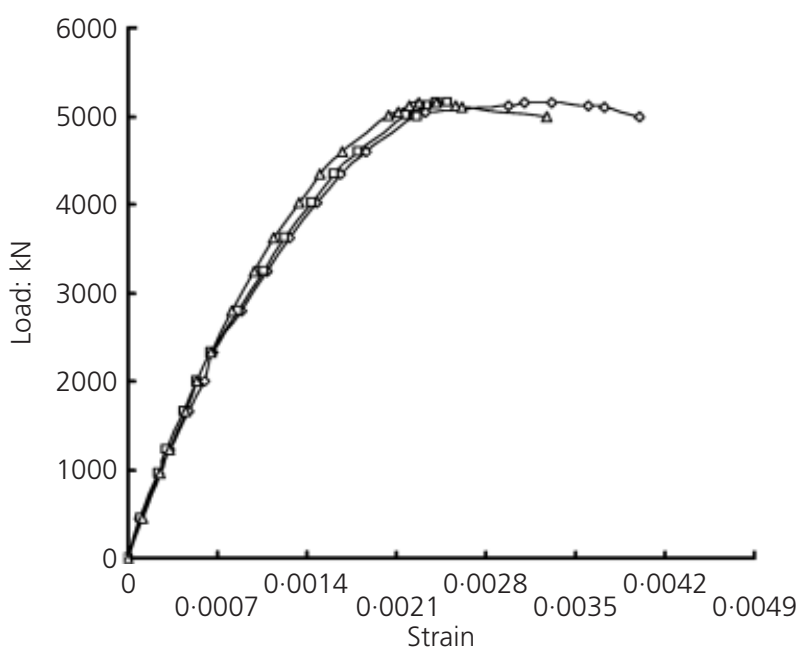

(e)

Figure 8. Load-strain curves of concentrically loaded columns:

(a) RC30-0.42-CON; (b) RC28-0.75-CON; (c) RC38-1.18-CON;

(d) RC50-0.75-CON; (e) RC41-0.75-CON 


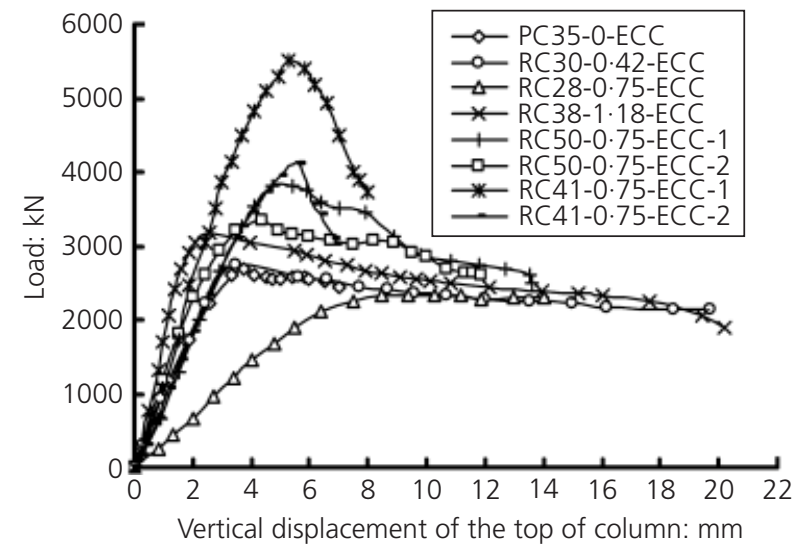

(a)

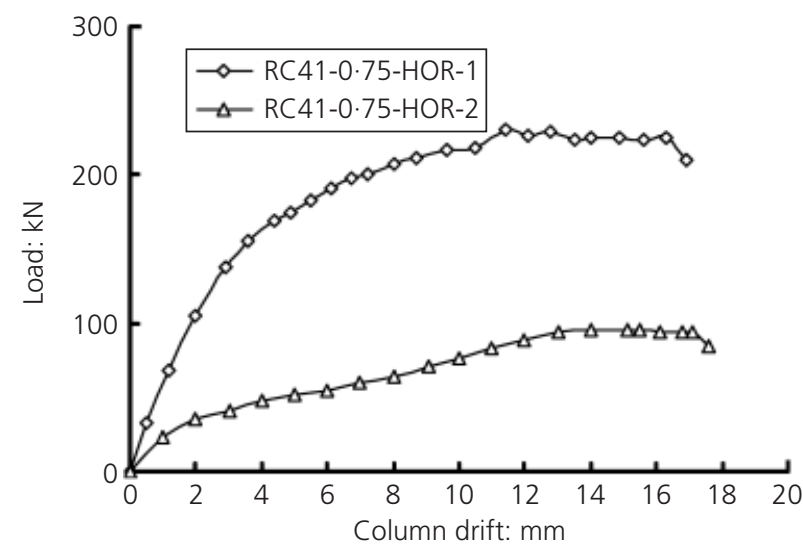

(b)

Figure 9. (a) Axial load against vertical displacement for eccentrically loaded specimens. (b) Horizontal load against column drift for horizontally loaded specimens gradient. This can be reasonably explained by the tests on concrete micro-cracking reported by Sturman et al. (1965) who observed that in columns subjected to concentric axial load, extensive micro-cracking of concrete (5 in $(127 \mathrm{~mm})$ length) occurred at low concrete strain (0.002) (see Figure 9 in Sturman et al. (1965)). Nevertheless, in columns subjected to eccentric axial load, less micro-cracking was observed at the same strain and extensive micro-cracking occurred at larger concrete strains of about $0 \cdot 0030-0 \cdot 0035$. These observations can logically explain the obtained non-linear variation of equivalent concrete stresses with strain gradient as follows.

(a) Initially, when the column was subjected to small strain gradient (i.e. large axial load with a small moment), large concrete cracking occurred at a small concrete strain of about 0.002 and the concrete stress could not be further increased due to crack formation.

(b) For columns subjected to larger strain gradient (i.e. medium axial load with a larger moment), significant concrete cracking occurred at a larger concrete strain (0.0030$0 \cdot 0035)$. Hence, larger maximum concrete stress was developed because the formation of micro-cracking was delayed.

(c) However, for columns subjected to an even larger strain gradient (i.e. low axial load with a very large moment or pure flexure), the maximum concrete stress could not increase further. This is because the strain $(0 \cdot 0030-0.0035)$ at maximum concrete stress has already reached the ultimate concrete strain, $\varepsilon_{\mathrm{cu}}$, which is equal to 0.0035 as per Eurocode 2 (CEN, 2004). At this stage, no further increase in concrete stress should occur; otherwise, the flexural strength of the columns would occur at a much larger strain than $\varepsilon_{\mathrm{cu}}$, which

\begin{tabular}{|c|c|c|c|c|c|c|c|c|c|c|}
\hline Specimen code & $\begin{array}{c}f_{\mathrm{cu}}: \mathrm{MPa} \\
\text { (testing day) }\end{array}$ & $\sigma_{\max }: \mathrm{MPa}$ & $\mathrm{c}: \mathrm{mm}$ & $k_{1}$ & $k_{2}$ & $k_{3}$ & $k_{1} k_{3}$ & $\varepsilon_{\mathrm{cu}}$ & $\phi: \mathrm{rad} / \mathrm{m}$ & $d / c$ \\
\hline \multicolumn{11}{|c|}{ Plain concrete specimen } \\
\hline PC35-0-ECC & $35 \cdot 3$ & $28 \cdot 1$ & $199 \cdot 2$ & 0.71 & 0.40 & $1 \cdot 33$ & 0.95 & 0.0035 & 0.0176 & $2 \cdot 01^{a}$ \\
\hline \multicolumn{11}{|c|}{ Reinforced concrete specimens } \\
\hline RC30-0.42-ECC & $35 \cdot 9$ & $28 \cdot 1$ & $217 \cdot 7$ & 0.67 & 0.40 & $1 \cdot 27$ & 0.85 & 0.0031 & 0.0142 & 1.72 \\
\hline RC28-0.75-ECC & $31 \cdot 6$ & $23 \cdot 5$ & $229 \cdot 0$ & 0.79 & $0 \cdot 39$ & $1 \cdot 14$ & 0.90 & 0.0031 & 0.0135 & $1 \cdot 62$ \\
\hline RC38-1.18-ECC & $42 \cdot 8$ & $29 \cdot 3$ & $287 \cdot 0$ & 0.75 & 0.40 & $0 \cdot 76$ & $0 \cdot 57$ & 0.0029 & 0.0101 & $1 \cdot 29$ \\
\hline RC50-0.75-ECC-1 & $58 \cdot 2$ & $40 \cdot 1$ & $252 \cdot 0$ & $0 \cdot 70$ & $0 \cdot 39$ & 0.90 & 0.63 & 0.0035 & 0.0139 & 1.44 \\
\hline RC50-0.75-ECC-2 & $58 \cdot 2$ & $40 \cdot 1$ & $223 \cdot 0$ & 0.68 & $0 \cdot 38$ & 0.93 & 0.63 & 0.0030 & 0.0135 & 1.63 \\
\hline RC41-0.75-ECC-1 & $49 \cdot 1$ & $28 \cdot 7$ & $406 \cdot 0$ & $0 \cdot 81$ & $0 \cdot 38$ & $0 \cdot 76$ & 0.61 & 0.0033 & 0.0081 & 0.90 \\
\hline RC41-0.75-ECC-2 & $49 \cdot 1$ & $28 \cdot 7$ & $234 \cdot 0$ & 0.84 & $0 \cdot 38$ & 0.96 & $0 \cdot 81$ & 0.0033 & 0.0141 & $1 \cdot 56$ \\
\hline RC41-0.75-HOR-1 & $46 \cdot 4$ & $28 \cdot 7$ & $76 \cdot 0$ & 0.66 & $0 \cdot 38$ & $1 \cdot 29$ & $0 \cdot 84$ & 0.0033 & 0.0434 & 4.79 \\
\hline RC41-0.75-HOR-2 & $46 \cdot 4$ & $28 \cdot 7$ & $27 \cdot 0$ & 0.66 & $0 \cdot 38$ & $1 \cdot 31$ & 0.86 & 0.0028 & 0.1148 & $13 \cdot 48$ \\
\hline Average & $46 \cdot 0$ & $30 \cdot 4$ & - & 0.73 & 0.40 & 1.02 & 0.76 & 0.0031 & - & - \\
\hline
\end{tabular}

${ }^{a} d$ is effective depth of RC specimens and is taken as the overall depth of column for the PC specimen

Table 4. Obtained values of $k_{1}, k_{2}$ and $k_{3}$ 


\begin{tabular}{llllll}
\hline Research & $f_{c}^{\prime}:$ MPa & $k_{1}$ & $k_{2}$ & $k_{3}$ & $k_{1} k_{3}$ \\
\hline Hognestad et al. (1955) & 27.6 & 0.79 & 0.45 & 0.94 & 0.74 \\
Hognestad et al. (1955) & 34.5 & 0.75 & 0.44 & 0.92 & 0.69 \\
Kaar et al. (1978) & 45.0 & 0.72 & 0.40 & 0.97 & 0.70 \\
Mansur et al. (1997) & 57.2 & 0.70 & 0.42 & 0.98 & 0.69 \\
Swartz et al. (1985) & 57.0 & 0.71 & 0.42 & 0.98 & 0.70 \\
Tan and Nguyen (2004, 2005) & 48.3 & 0.70 & 0.38 & 0.93 & 0.65 \\
Current work & $46.0^{a}$ & 0.73 & 0.40 & 1.02 & 0.76 \\
\hline
\end{tabular}

${ }^{\mathrm{a}} \mathrm{f}_{\mathrm{cu}}$ (in $\mathrm{MPa}$ )

Table 5. Comparisons of $k_{1}, k_{2}$ and $k_{3}$

\begin{tabular}{lccccc}
\hline Specimen code & $\alpha$ & $\beta$ & $\varepsilon_{\text {cu }}$ & $\phi:$ rad/m & $d / c$ \\
\hline PC35-0-CON & 0.80 & - & - & 0.0 & 0.0 \\
RC30-0.42-CON & 0.66 & - & - & 0.0 & 0.0 \\
RC28-0.75-CON & 0.70 & - & - & 0.0 & 0.0 \\
RC38-1.18-CON & 0.68 & - & - & 0.0 & 0.0 \\
RC50-0.75-CON & 0.76 & - & - & 0.0 & 0.0 \\
RC41-0.75-CON & 0.68 & - & - & 0.0 & 0.0 \\
Average & 0.71 & - & - & 0.0 & 0.0 \\
PC35-0-ECC & 1.18 & 0.80 & 0.0035 & 0.0176 & 2.01 a \\
RC30-0.42-ECC & 1.06 & 0.81 & 0.0031 & 0.0142 & 1.72 \\
RC28-0.75-ECC & 1.15 & 0.78 & 0.0031 & 0.0135 & 1.62 \\
RC38-1.18-ECC & 0.72 & 0.79 & 0.0029 & 0.0101 & 1.29 \\
RC50-0.75-ECC-1 & 0.80 & 0.79 & 0.0035 & 0.0139 & 1.44 \\
RC50-0.75-ECC-2 & 0.82 & 0.77 & 0.0030 & 0.0135 & 1.63 \\
RC41-0.75-ECC-1 & 0.80 & 0.76 & 0.0033 & 0.0081 & 0.90 \\
RC41-0.75-ECC-2 & 1.07 & 0.76 & 0.0033 & 0.0141 & 1.56 \\
RC41-0.75-HOR-1 & 1.10 & 0.77 & 0.0033 & 0.0434 & 4.79 \\
RC41-0.75-HOR-2 & 1.15 & 0.75 & 0.0028 & 0.1148 & 13.48 \\
Average & - & 0.78 & 0.0031 & - & - \\
\hline
\end{tabular}

${ }^{a} d$ is effective depth of RC specimens and is taken as the overall depth of column for the PC specimen

Table 6. Obtained values of equivalent rectangular stress block parameters and strain gradient

has never been observed in previous experimental tests for unconfined columns.

From the above comparison, it is believed that the current design codes can predict fairly accurately the strengths of RC columns subjected to pure axial load without strain gradient, but underestimate the strengths of RC beams and columns subjected to flexure with or without axial load. This is because the equivalent rectangular concrete stress that is currently adopted for flexural strength design does not take into account the enhancement of concrete stress due to the strain gradient effect.

\section{Modification of stress block parameters by incorporating strain gradient effects}

The stress block parameters of $k_{1}, k_{2}, k_{3}, \alpha$ and $\beta$ obtained in this study are summarised in Tables 4 and 6 , together with their corresponding strain gradients $\phi=\varepsilon_{\mathrm{cu}} / c(\mathrm{rad} / \mathrm{m})$. However, since $\phi$ is non-dimensionless, the formula that correlates these stress block parameters to $\phi$ will include the effect of 
column dimensions. In order to eliminate the column size effect, a dimensionless factor, $d / c$, is proposed to replace $\phi$ to represent strain gradient, where $d$ and $c$ are effective and neutral axis depths respectively. To investigate the relationships of $k_{1}, k_{2}, k_{3}, \alpha$ and $\beta$ with strain gradient in dimensionless form, the values of these parameters obtained in the present study are plotted against $d / c$ in Figures 10 and 11. It is apparent from Figures 10(a), 10(b) and 11(b) that $k_{1}, k_{2}$ and $\beta$ remain fairly constant at $0.73,0.40$ and 0.80 , respectively. However, Figures $10(\mathrm{c})$ and 11(a) show that $k_{3}$ and $\alpha$ increase with strain gradient in a tri-linear manner. Two formulas are

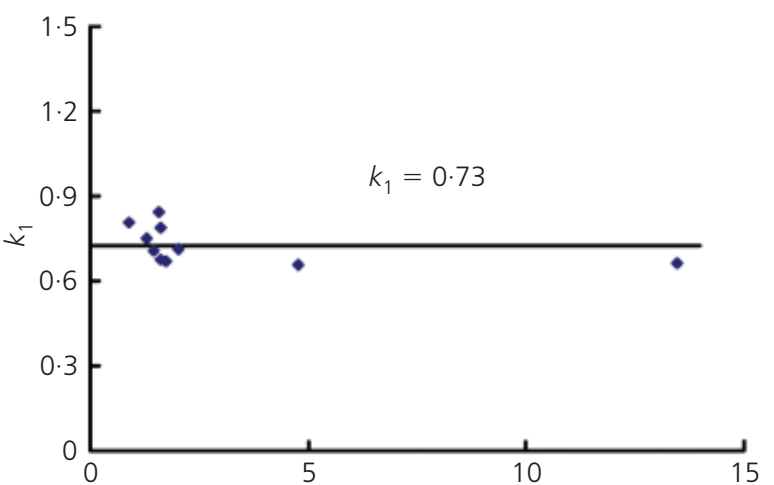

(a)

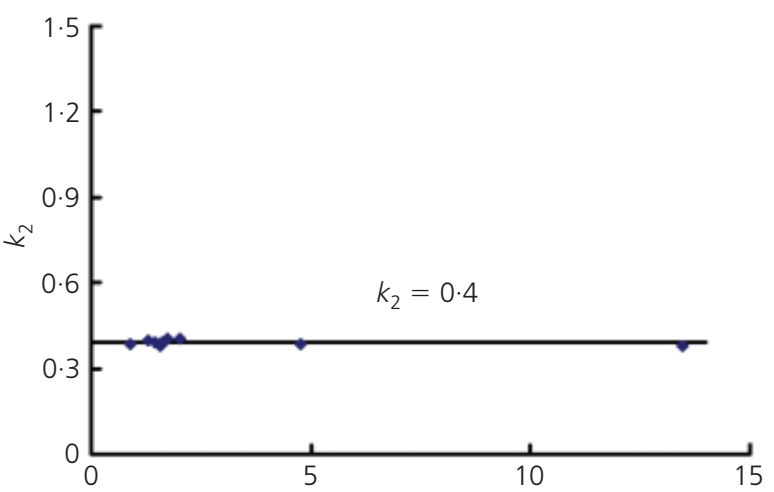

(b)

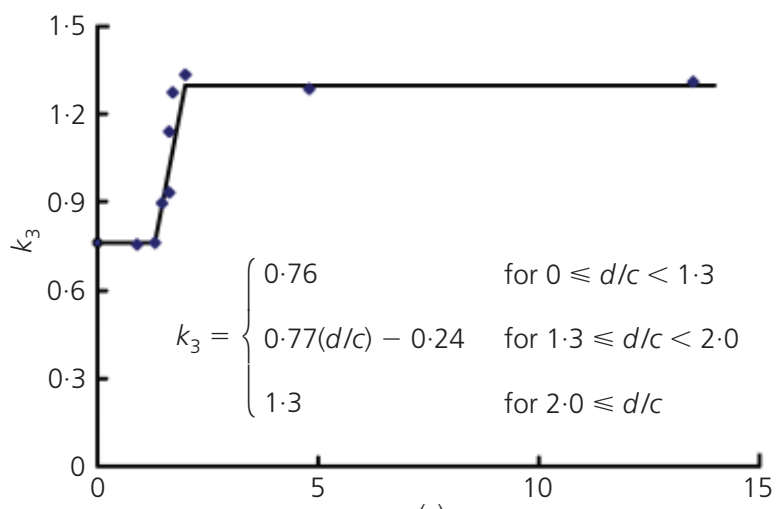

(c)

Figure 10. Relationships of $k_{1}, k_{2}$ and $k_{3}$ with strain gradient $d / c$

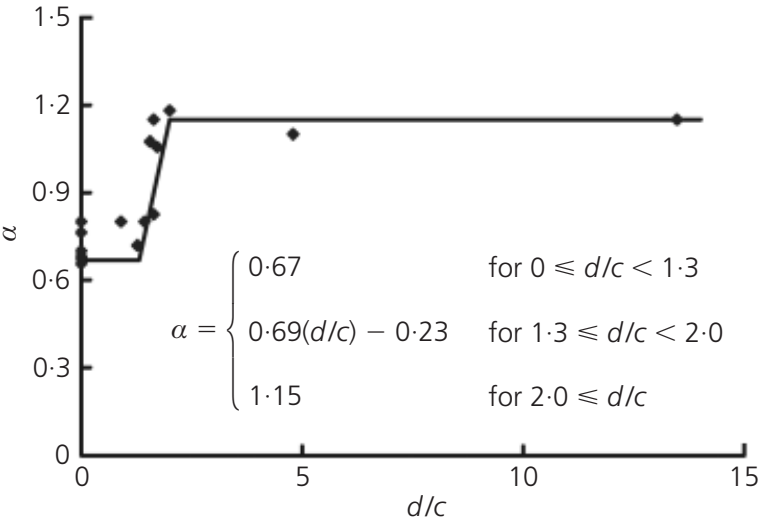

(a)

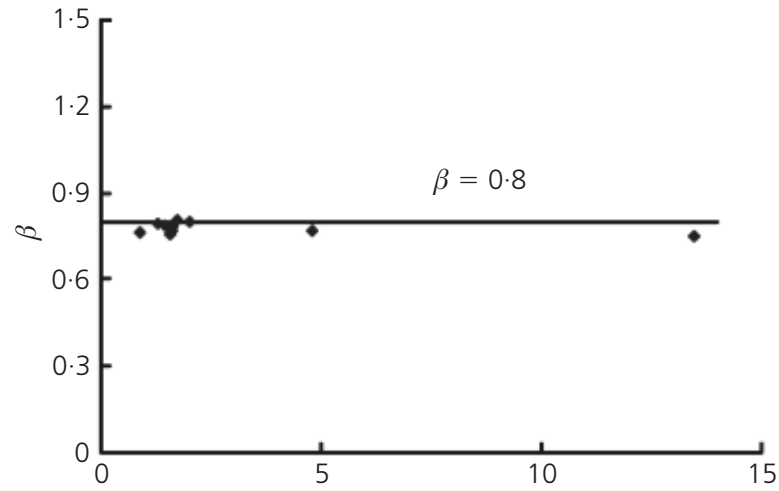

(b)

Figure 11. Relationships of $\alpha$ and $\beta$ with strain gradient $d / c$

thus proposed to correlate $k_{3}$ and $\alpha$ with strain gradient using linear regression analysis

$$
\text { 6. } k_{3}= \begin{cases}0.76 & \text { for } 0 \leqslant d / c<1.3 \\ 0.77(d / c)-0.24 & \text { for } 1.3 \leqslant d / c<2.0 \\ 1.3 & \text { for } 2.0 \leqslant d / c\end{cases}
$$

$$
\alpha= \begin{cases}0.67 & \text { for } 0 \leqslant d / c<1.3 \\ 0.69(d / c)-0.23 & \text { for } 1.3 \leqslant d / c<2.0 . . \\ 1.15 & \text { for } 2.0 \leqslant d / c\end{cases}
$$

For the obtained value of $k_{2}=0 \cdot 40$, the following fixed value of $\beta$ is proposed

8. $\beta=2 k_{2}=2 \times 0.4=0.8$

From Table 4, the value of ultimate concrete strain for design is taken as $\varepsilon_{\mathrm{cu}}=0.0031$ 
Moment: kNm

$M_{\mathrm{p}} \quad M_{\mathrm{ACl}} \quad M_{\mathrm{EC}} \quad M_{\mathrm{NZ}}$

(1)
(2)

(3)
(1)

(5)

(4)
$(2)$

$\overline{(5)}$

(3)

$\overline{(5)}$

(4)

Pecce and Fabbrocino (1999)

\begin{tabular}{lrrrrrrrrrr}
\hline A & 41.3 & 103.8 & 97.0 & 97.0 & 97.0 & 104.0 & 1.00 & 0.93 & 0.93 & 0.93 \\
B & 41.3 & 46.8 & 45.0 & 45.0 & 45.0 & 49.6 & 0.94 & 0.91 & 0.91 & 0.91 \\
C & 42.3 & 693.4 & 636.7 & 636.7 & 636.7 & 712.5 & 0.97 & 0.89 & 0.89 & 0.89 \\
\hline
\end{tabular}

Ashour (2000)

\begin{tabular}{lrrrrrrrrrr}
\hline B-N2 & 48.6 & 55.4 & 53.6 & 53.6 & 53.6 & 58.2 & 0.95 & 0.92 & 0.92 & 0.92 \\
B-N3 & 48.6 & 81.1 & 77.1 & 77.1 & 77.1 & 80.6 & 1.01 & 0.96 & 0.96 & 0.96 \\
B-N4 & 48.6 & 105.6 & 98.4 & 98.4 & 98.4 & 99.6 & 1.06 & 0.99 & 0.99 & 0.99 \\
\hline
\end{tabular}

Pam et al. (2001)

\begin{tabular}{|c|c|c|c|c|c|c|c|c|c|c|}
\hline 1 & 29.9 & $58 \cdot 3$ & $56 \cdot 1$ & $56 \cdot 1$ & $56 \cdot 1$ & 77.6 & 0.75 & 0.72 & 0.72 & 0.72 \\
\hline 2 & $29 \cdot 4$ & 85.0 & 80 & $80 \cdot 0$ & 80 & $103 \cdot 5$ & 0.82 & 0.77 & 0.77 & 0.77 \\
\hline 3 & $29 \cdot 1$ & 128.5 & $114 \cdot 1$ & 111.5 & $114 \cdot 1$ & 126.5 & 1.02 & 0.90 & 0.88 & 0.90 \\
\hline 4 & $33 \cdot 8$ & $122 \cdot 6$ & $112 \cdot 0$ & $112 \cdot 7$ & $112 \cdot 0$ & $129 \cdot 0$ & 0.95 & 0.87 & 0.87 & 0.87 \\
\hline 5 & 37.1 & 148.4 & $133 \cdot 8$ & 134.8 & $133 \cdot 8$ & $142 \cdot 8$ & 1.04 & 0.94 & 0.94 & 0.94 \\
\hline 6 & 34.6 & 173.9 & $144 \cdot 8$ & 139.6 & $144 \cdot 8$ & $162 \cdot 0$ & 1.07 & 0.89 & 0.86 & 0.89 \\
\hline 7 & 46.9 & 158.4 & $145 \cdot 7$ & $162 \cdot 3$ & $145 \cdot 7$ & 164.6 & 0.96 & 0.89 & 0.89 & 0.89 \\
\hline 8 & $45 \cdot 7$ & $176 \cdot 8$ & $160 \cdot 6$ & $161 \cdot 4$ & $160 \cdot 6$ & $166 \cdot 2$ & 1.06 & 0.97 & 0.97 & 0.97 \\
\hline
\end{tabular}

Debernardi and Taliano (2002)

\begin{tabular}{|c|c|c|c|c|c|c|c|c|c|c|}
\hline T1 & $27 \cdot 7$ & $11 \cdot 1$ & $10 \cdot 8$ & $10 \cdot 8$ & $10 \cdot 8$ & $13 \cdot 6$ & 0.82 & 0.79 & 0.79 & 0.79 \\
\hline T2 & $27 \cdot 7$ & $21 \cdot 3$ & $20 \cdot 5$ & $20 \cdot 6$ & $20 \cdot 5$ & $23 \cdot 6$ & 0.90 & 0.87 & 0.87 & 0.87 \\
\hline T3 & $27 \cdot 7$ & $30 \cdot 9$ & 28.9 & $29 \cdot 3$ & 28.9 & $32 \cdot 5$ & 0.95 & 0.89 & 0.90 & 0.89 \\
\hline T4 & $27 \cdot 7$ & $48 \cdot 7$ & $46 \cdot 9$ & $46 \cdot 8$ & $46 \cdot 9$ & $59 \cdot 8$ & $0 \cdot 81$ & 0.78 & 0.78 & 0.78 \\
\hline T5 & $27 \cdot 7$ & $92 \cdot 6$ & 93.1 & 93.1 & 93.1 & $107 \cdot 5$ & 0.86 & 0.87 & 0.87 & 0.87 \\
\hline T6 & $27 \cdot 7$ & $176 \cdot 9$ & $170 \cdot 5$ & $171 \cdot 2$ & $170 \cdot 5$ & $192 \cdot 4$ & 0.92 & 0.89 & 0.89 & 0.89 \\
\hline T7 & $27 \cdot 7$ & $242 \cdot 0$ & $217 \cdot 2$ & $221 \cdot 7$ & $217 \cdot 2$ & $221 \cdot 6$ & 1.09 & 0.98 & 1.00 & 0.98 \\
\hline T8 & $27 \cdot 7$ & $81 \cdot 4$ & $81 \cdot 1$ & $81 \cdot 2$ & $81 \cdot 1$ & 93.9 & 0.87 & 0.86 & 0.86 & 0.86 \\
\hline T9 & $27 \cdot 7$ & $152 \cdot 0$ & $152 \cdot 0$ & $151 \cdot 9$ & $152 \cdot 0$ & $182 \cdot 7$ & 0.83 & 0.83 & 0.83 & 0.83 \\
\hline T10 & $27 \cdot 7$ & $322 \cdot 9$ & $324 \cdot 6$ & $324 \cdot 7$ & $324 \cdot 6$ & $330 \cdot 4$ & 0.98 & 0.98 & 0.98 & 0.98 \\
\hline
\end{tabular}

Lam et al. (2008)

\begin{tabular}{lrrrrrrrrrr}
\hline L-C1 & 29.8 & 15.0 & 14.6 & 14.6 & 14.6 & 14.2 & 1.06 & 1.03 & 1.03 & 1.03 \\
L-D & 29.8 & 10.1 & 9.8 & 9.8 & 9.8 & 11.6 & 0.87 & 0.84 & 0.84 & 0.84 \\
L-E & 29.8 & 30.1 & 25.9 & 26.0 & 25.9 & 29.4 & 1.02 & 0.88 & 0.89 & 0.88 \\
\hline
\end{tabular}

Fathifazl et al. (2009)

\begin{tabular}{lrrrrrrrrrr}
\hline EV-1.5N & 43.5 & 83.4 & 79.4 & 79.5 & 79.4 & 86.9 & 0.96 & 0.91 & 0.91 & 0.91 \\
EV-2.7N & 43.5 & 113.4 & $108 \cdot 3$ & 108.4 & 108.3 & 126.4 & 0.90 & 0.86 & 0.86 & 0.86 \\
CG-2.7N & 43.5 & 112.9 & 106.3 & 106.3 & 106.3 & 118.5 & 0.95 & 0.90 & 0.90 & 0.90 \\
Average & & & & & & & 0.95 & 0.89 & 0.90 & 0.89
\end{tabular}

Table 7. Proposed strength comparisons of beams 


\section{Verification of the proposed stress block parameters}

The applicability of the proposed stress block parameters (i.e. $\alpha, \beta$ and $\varepsilon_{\mathrm{cu}}$ ) was verified by comparing the measured flexural strengths obtained experimentally by other researchers. The flexural strengths predicted using the proposed stress block parameters, $\boldsymbol{M}_{\mathrm{p}}$, were compared with experimentally measured strengths, $\boldsymbol{M}_{\mathrm{t}}$, and the strengths calculated using various RC design codes (i.e. $\boldsymbol{M}_{\mathrm{ACI}}$ based on ACI 318 (ACI, 2008), $\boldsymbol{M}_{\mathrm{EC}}$ based on Eurocode 2 (CEN, 2004) and $\boldsymbol{M}_{\mathrm{NZ}}$ based on NZS 3101 (SNZ, 2006). The comparisons are shown in Tables 7 to 11 .

Table 7 shows the strength comparison of beams subjected to pure flexure (Ashour, 2000; Debernardi and Taliano, 2002; Fathifazl et al., 2009; Lam et al., 2008; Pam et al., 2001; Pecce and Fabbrocino, 1999), while Tables 8 to 11 show the strength comparisons of columns subjected to low axial load $\left(0<\boldsymbol{P} / A_{\mathrm{g}} f_{\mathrm{c}}^{\prime} \leqslant\right.$ 0.2) (Marefat et al., 2005; Mo and Wang, 2000; Tao and Yu, 2008; Watson and Park, 1994), medium axial load (0.2 $\left.<\boldsymbol{P} / A_{\mathrm{g}} f_{\mathrm{c}}^{\prime} \leqslant 0 \cdot 5\right)$ (Lam et al., 2003; Marefat et al., 2005, 2006; Mo and Wang, 2000;
Sheikh and Khoury, 1993; Tao and Yu, 2008; Watson and Park, 1994), high axial load (0.5 $\left.<\boldsymbol{P} / A_{\mathrm{g}} f_{\mathrm{c}}^{\prime} \leqslant 0 \cdot 7\right)$ (Ho and Pam, 2003; Lam et al., 2003; Sheikh and Yeh, 1990; Sheikh et al., 1994; Watson and Park, 1994) and ultra-high axial load level $(0.7<$ $\boldsymbol{P} / A_{\mathrm{g}} f_{\mathrm{c}}^{\prime}$ ) (Nemecek et al., 2005; Sheikh and Khoury, 1993; Sheikh and Yeh, 1990; Sheikh et al., 1994) (P is compressive axial load, $A_{\mathrm{g}}$ is the gross area of concrete and $f_{\mathrm{c}}^{\prime}$ is the concrete cylinder strength). It should be noted that the concrete cylinder strengths reported by other researchers were converted to cube strength using $f_{\mathrm{c}}^{\prime}=0 \cdot 8 f_{\mathrm{cu}}$ in the comparison. From the tables, the following conclusions may be drawn.

(a) The flexural strength evaluated with the proposed equivalent rectangular stress block parameters $\alpha, \beta$ and $\varepsilon_{\mathrm{cu}}$, which take into account the strain gradient effects, results in a better estimation than that predicted by the current design codes for $\mathrm{RC}$ beams and columns subjected to low and medium axial load levels.

(b) For RC columns subjected to high and ultra-high axial load levels, the flexural strengths evaluated with $\alpha, \beta$ and $\varepsilon_{\mathrm{cu}}$, are similar to those predicted by current design codes.

\begin{tabular}{|c|c|c|c|c|c|c|c|c|c|c|c|}
\hline \multirow[t]{2}{*}{ Specimen code } & \multirow{2}{*}{$f_{\mathrm{c}}^{\prime}=0.8 f_{\mathrm{cu}}: \mathrm{MPa}$} & \multirow{2}{*}{$P / A_{g} f_{c}^{\prime}$} & \multicolumn{5}{|c|}{ Moment: kNm } & \multirow{2}{*}{$\frac{(1)}{(5)}$} & \multirow{2}{*}{$\frac{(2)}{(5)}$} & \multirow{2}{*}{$\frac{(3)}{(5)}$} & \multirow{2}{*}{$\frac{(4)}{(5)}$} \\
\hline & & & $\begin{array}{l}M_{\mathrm{p}} \\
(1)\end{array}$ & $\begin{array}{c}M_{\mathrm{ACl}} \\
(2)\end{array}$ & $\begin{array}{c}M_{\mathrm{EC}} \\
\text { (3) }\end{array}$ & $\begin{array}{c}M_{\mathrm{NZ}} \\
(4)\end{array}$ & $\begin{array}{l}M_{\mathrm{t}} \\
(5)\end{array}$ & & & & \\
\hline
\end{tabular}

Watson and Park (1994)

\begin{tabular}{|c|c|c|c|c|c|c|c|c|c|c|c|}
\hline 1 & $47 \cdot 0$ & $0 \cdot 100$ & $323 \cdot 5$ & $302 \cdot 0$ & $306 \cdot 9$ & $302 \cdot 0$ & $335 \cdot 2$ & 0.97 & 0.90 & 0.92 & 0.90 \\
\hline \multicolumn{12}{|c|}{ Mo and Wang (2000) } \\
\hline C1-1 & $24 \cdot 9$ & $0 \cdot 113$ & $335 \cdot 3$ & $300 \cdot 5$ & $305 \cdot 1$ & $300 \cdot 5$ & $351 \cdot 4$ & 0.95 & 0.86 & 0.87 & 0.86 \\
\hline C1-2 & $26 \cdot 7$ & $0 \cdot 106$ & $340 \cdot 1$ & $303 \cdot 8$ & $308 \cdot 2$ & $303 \cdot 8$ & 374.6 & 0.91 & 0.81 & 0.82 & 0.81 \\
\hline C1-3 & $26 \cdot 1$ & $0 \cdot 108$ & $338 \cdot 0$ & $302 \cdot 8$ & $307 \cdot 2$ & $302 \cdot 8$ & $427 \cdot 7$ & 0.79 & 0.71 & 0.72 & 0.71 \\
\hline C2-1 & $25 \cdot 3$ & 0.167 & 361.0 & $319 \cdot 1$ & $326 \cdot 8$ & $319 \cdot 1$ & $347 \cdot 3$ & 1.04 & 0.92 & 0.94 & 0.92 \\
\hline$C 2-2$ & $27 \cdot 1$ & 0.156 & $365 \cdot 6$ & $325 \cdot 2$ & $330 \cdot 5$ & $325 \cdot 2$ & $399 \cdot 9$ & 0.92 & 0.81 & 0.83 & 0.81 \\
\hline$C 2-3$ & $26 \cdot 8$ & 0.158 & $364 \cdot 5$ & $324 \cdot 4$ & $329 \cdot 7$ & $324 \cdot 4$ & $427 \cdot 2$ & 0.85 & 0.76 & 0.77 & 0.76 \\
\hline
\end{tabular}

Marefat et al. (2005)

\begin{tabular}{|c|c|c|c|c|c|c|c|c|c|c|c|}
\hline STCM-9 & $24 \cdot 0$ & 0.190 & $25 \cdot 7$ & $22 \cdot 8$ & $22 \cdot 5$ & $22 \cdot 5$ & $23 \cdot 3$ & $1 \cdot 10$ & 0.97 & 0.98 & 0.97 \\
\hline SBCC-7 & 27.0 & 0.160 & $43 \cdot 5$ & 41.6 & 41.9 & 41.7 & $45 \cdot 1$ & 0.96 & 0.92 & 0.93 & 0.92 \\
\hline
\end{tabular}

Tao and Yu (2008)

\begin{tabular}{|c|c|c|c|c|c|c|c|c|c|c|c|}
\hline US-3U & $49 \cdot 2$ & 0.108 & $17 \cdot 9$ & $16 \cdot 5$ & $16 \cdot 5$ & $16 \cdot 5$ & $15 \cdot 9$ & $1 \cdot 13$ & 1.04 & 1.04 & 1.04 \\
\hline BS-3U & $49 \cdot 8$ & 0.098 & $16 \cdot 7$ & $15 \cdot 4$ & $15 \cdot 4$ & $15 \cdot 4$ & 14.6 & $1 \cdot 14$ & 1.05 & 1.05 & 1.05 \\
\hline BS-4U & $49 \cdot 8$ & 0.067 & 14.9 & $13 \cdot 6$ & $13 \cdot 7$ & $13 \cdot 6$ & $13 \cdot 3$ & $1 \cdot 12$ & 1.02 & 1.03 & 1.02 \\
\hline Average & & & & & & & & 0.99 & 0.90 & 0.91 & 0.90 \\
\hline
\end{tabular}

Table 8. Proposed strength comparisons of columns subjected to low axial load level 


\begin{tabular}{|c|c|c|c|c|c|c|c|c|c|c|c|}
\hline \multirow[t]{2}{*}{ Specimen code } & \multirow[t]{2}{*}{$f_{c}^{\prime}=0.8 f_{\mathrm{cu}}: \mathrm{MPa}$} & \multirow[t]{2}{*}{$P / A_{g} f_{c}^{\prime}$} & \multicolumn{5}{|c|}{ Moment: kNm } & \multirow{2}{*}{$\frac{(1)}{(5)}$} & \multirow{2}{*}{$\frac{(2)}{(5)}$} & \multirow{2}{*}{$\frac{(3)}{(5)}$} & $\frac{(4)}{(5)}$ \\
\hline & & & $\begin{array}{l}M_{\mathrm{p}} \\
(1)\end{array}$ & $\begin{array}{c}M_{\mathrm{ACl}} \\
(2)\end{array}$ & $\begin{array}{c}M_{\mathrm{EC}} \\
\text { (3) }\end{array}$ & $\begin{array}{c}M_{\mathrm{NZ}} \\
\text { (4) }\end{array}$ & $\begin{array}{l}M_{\mathrm{t}} \\
\text { (5) }\end{array}$ & & & & \\
\hline
\end{tabular}

Sheikh and Khoury (1993)

\begin{tabular}{|c|c|c|c|c|c|c|c|c|c|c|c|}
\hline AS-19 & $32 \cdot 3$ & 0.470 & 234.4 & 178.5 & 183.9 & $179 \cdot 2$ & $219 \cdot 7$ & 1.06 & $0 \cdot 81$ & 0.84 & 0.82 \\
\hline \multicolumn{12}{|c|}{ Watson and Park (1994) } \\
\hline 2 & $44 \cdot 0$ & 0.300 & $493 \cdot 3$ & $405 \cdot 9$ & $410 \cdot 2$ & $406 \cdot 0$ & $486 \cdot 0$ & 1.02 & 0.84 & 0.84 & 0.84 \\
\hline 3 & 44.0 & 0.300 & $493 \cdot 3$ & $405 \cdot 9$ & $410 \cdot 2$ & $406 \cdot 0$ & $479 \cdot 1$ & 1.03 & 0.85 & 0.86 & 0.85 \\
\hline 4 & $40 \cdot 0$ & 0.300 & $462 \cdot 6$ & $382 \cdot 1$ & $385 \cdot 3$ & $382 \cdot 3$ & $448 \cdot 1$ & 1.03 & 0.85 & 0.86 & 0.85 \\
\hline 5 & 41.0 & 0.500 & 572.8 & 372.9 & 383.2 & 373.4 & $525 \cdot 8$ & 1.09 & 0.71 & 0.73 & 0.71 \\
\hline 6 & $40 \cdot 0$ & 0.500 & $562 \cdot 4$ & $367 \cdot 2$ & $376 \cdot 7$ & $367 \cdot 8$ & $526 \cdot 4$ & 1.07 & 0.70 & 0.72 & 0.70 \\
\hline
\end{tabular}

Mo and Wang (2000)

\begin{tabular}{|c|c|c|c|c|c|c|c|c|c|c|c|}
\hline C3-1 & $26 \cdot 4$ & 0.213 & $386 \cdot 9$ & $333 \cdot 3$ & 343.9 & $333 \cdot 3$ & 353.4 & $1 \cdot 10$ & 0.94 & 0.97 & 0.94 \\
\hline C $3-2$ & $27 \cdot 5$ & 0.205 & $390 \cdot 4$ & $337 \cdot 7$ & $348 \cdot 2$ & $337 \cdot 7$ & $395 \cdot 5$ & 0.99 & 0.85 & 0.88 & 0.85 \\
\hline C $3-3$ & $26 \cdot 9$ & 0.209 & 388.2 & 335.4 & $345 \cdot 9$ & 335.4 & $423 \cdot 8$ & 0.92 & 0.79 & 0.82 & 0.79 \\
\hline
\end{tabular}

Lam et al. (2003)

\begin{tabular}{|c|c|c|c|c|c|c|c|c|c|c|c|}
\hline$x 6$ & 31.9 & 0.450 & $33 \cdot 1$ & 28.5 & $29 \cdot 0$ & 28.6 & $37 \cdot 1$ & 0.89 & 0.77 & 0.78 & 0.77 \\
\hline X7 & 35.7 & 0.450 & $36 \cdot 7$ & $29 \cdot 7$ & 30.5 & $29 \cdot 8$ & $37 \cdot 1$ & 0.99 & 0.80 & 0.82 & 0.80 \\
\hline
\end{tabular}

Marefat et al. (2005)

\begin{tabular}{|c|c|c|c|c|c|c|c|c|c|c|c|}
\hline NTCM-14 & $20 \cdot 1$ & $0 \cdot 310$ & $18 \cdot 7$ & $16 \cdot 0$ & $16 \cdot 0$ & $16 \cdot 0$ & $16 \cdot 8$ & $1 \cdot 11$ & 0.95 & 0.95 & 0.95 \\
\hline NBCC-12 & $25 \cdot 2$ & 0.230 & $22 \cdot 5$ & $22 \cdot 0$ & $22 \cdot 4$ & $22 \cdot 0$ & $21 \cdot 7$ & 1.04 & 1.01 & 1.03 & 1.01 \\
\hline NBCM-11 & 24.5 & 0.250 & $46 \cdot 8$ & 38.6 & 38.5 & 38.6 & 44.6 & 1.05 & 0.87 & 0.86 & 0.87 \\
\hline SBCM-8 & 28.0 & 0.220 & $52 \cdot 4$ & $46 \cdot 0$ & $46 \cdot 0$ & $46 \cdot 0$ & $58 \cdot 7$ & 0.89 & 0.78 & 0.78 & 0.78 \\
\hline
\end{tabular}

Marefat et al. (2006)

\begin{tabular}{|c|c|c|c|c|c|c|c|c|c|c|c|}
\hline NTMM-13 & $21 \cdot 0$ & $0 \cdot 310$ & $19 \cdot 1$ & $16 \cdot 3$ & $16 \cdot 4$ & $16 \cdot 3$ & $17 \cdot 3$ & $1 \cdot 10$ & 0.94 & 0.95 & 0.94 \\
\hline \multicolumn{12}{|c|}{ Tao and Yu (2008) } \\
\hline BS-2U & $49 \cdot 8$ & 0.230 & $24 \cdot 2$ & $21 \cdot 7$ & $21 \cdot 8$ & $21 \cdot 7$ & $25 \cdot 1$ & 0.96 & 0.86 & 0.87 & 0.86 \\
\hline Average & & & & & & & & 1.02 & $0 \cdot 84$ & 0.85 & 0.84 \\
\hline
\end{tabular}

Table 9. Proposed strength comparisons of columns subjected to medium axial load level

(c) For RC beams, the average ratio of the predicted to experimentally measured flexural strength is $0 \cdot 95$, whereas the average ratio of the code-predicted to measured strength is 0.89 . Therefore, it is evident that the proposed stress block parameters can improve the accuracy of flexural strength prediction by $6 \%$ on average.

(d) For RC columns subjected to low and medium axial load levels, the average ratios of the predicted to experimentally measured flexural strength are 0.99 and 1.02 , respectively, whereas the average ratios of the code-predicted to measured strengths are 0.90 and $0 \cdot 84$, respectively. The proposed stress block method can thus improve the accuracy of flexural strength prediction by $9 \%$ and $18 \%$ on average.

(e) For RC columns subjected to high and ultra-high axial load levels, the average ratios of the predicted to experimentally measured flexural strength are 0.86 and 0.92 , respectively, 


\begin{tabular}{|c|c|c|c|c|c|c|c|c|c|c|c|}
\hline \multirow[t]{2}{*}{ Specimen code } & \multirow[t]{2}{*}{$f_{\mathrm{c}}^{\prime}=0 \cdot 8 f_{\mathrm{cu}}: \mathrm{MPa}$} & \multirow[t]{2}{*}{$P / A_{g} f_{c}^{\prime}$} & \multicolumn{5}{|c|}{ Moment: kNm } & $\frac{(1)}{(5)}$ & $\frac{(2)}{(5)}$ & $\frac{(3)}{(5)}$ & $\frac{(4)}{(5)}$ \\
\hline & & & $\begin{array}{c}M_{\mathrm{p}} \\
(1)\end{array}$ & $\begin{array}{c}M_{\mathrm{ACl}} \\
(2)\end{array}$ & $\begin{array}{c}M_{\mathrm{EC}} \\
(3)\end{array}$ & $\begin{array}{c}M_{\mathrm{NZ}} \\
(4)\end{array}$ & $\begin{array}{l}M_{\mathrm{t}} \\
(5)\end{array}$ & & & & \\
\hline
\end{tabular}

Sheikh and Yeh (1990)

\begin{tabular}{|c|c|c|c|c|c|c|c|c|c|c|c|}
\hline$E-2$ & $31 \cdot 4$ & 0.610 & $152 \cdot 3$ & $160 \cdot 1$ & $163 \cdot 5$ & $160 \cdot 5$ & $169 \cdot 3$ & 0.89 & 0.95 & 0.97 & 0.95 \\
\hline A-3 & 31.8 & 0.610 & $151 \cdot 3$ & $162 \cdot 7$ & 161.9 & $163 \cdot 1$ & $197 \cdot 8$ & 0.77 & 0.82 & 0.82 & 0.82 \\
\hline $\mathrm{F}-4$ & $32 \cdot 2$ & 0.600 & $155 \cdot 1$ & $164 \cdot 8$ & $168 \cdot 0$ & $165 \cdot 2$ & 198.4 & 0.78 & 0.83 & 0.85 & 0.83 \\
\hline $\mathrm{F}-12$ & 33.4 & 0.600 & $155 \cdot 1$ & $156 \cdot 1$ & $157 \cdot 9$ & $156 \cdot 5$ & $161 \cdot 1$ & 0.96 & 0.97 & 0.98 & 0.97 \\
\hline A-16 & 33.9 & 0.600 & $156 \cdot 0$ & $157 \cdot 1$ & $159 \cdot 1$ & $157 \cdot 6$ & $157 \cdot 5$ & 0.99 & 1.00 & 1.01 & 1.00 \\
\hline
\end{tabular}

Sheikh et al. (1994)

\begin{tabular}{|c|c|c|c|c|c|c|c|c|c|c|c|}
\hline AS-3 & $33 \cdot 2$ & 0.600 & $154 \cdot 2$ & $167 \cdot 1$ & $169 \cdot 3$ & $167 \cdot 5$ & 192.9 & 0.80 & 0.87 & 0.88 & 0.87 \\
\hline $\mathrm{AS}-3 \mathrm{H}$ & $54 \cdot 1$ & 0.620 & 203.0 & 208.6 & $210 \cdot 2$ & $208 \cdot 3$ & 237.4 & 0.86 & 0.88 & 0.89 & 0.88 \\
\hline
\end{tabular}

Watson and Park (1994)

\begin{tabular}{|c|c|c|c|c|c|c|c|c|c|c|c|}
\hline 7 & $42 \cdot 0$ & 0.700 & $537 \cdot 7$ & $430 \cdot 3$ & $434 \cdot 0$ & $430 \cdot 3$ & $516 \cdot 8$ & 1.02 & 0.83 & 0.84 & 0.83 \\
\hline 8 & 39.0 & 0.700 & $529 \cdot 2$ & $407 \cdot 7$ & $411 \cdot 4$ & $407 \cdot 7$ & 524.5 & 1.01 & 0.77 & 0.78 & 0.77 \\
\hline
\end{tabular}

Ho and Pam (2003)

\begin{tabular}{|c|c|c|c|c|c|c|c|c|c|c|c|}
\hline BS-60-06-61-S & $51 \cdot 1$ & 0.675 & 361.9 & $373 \cdot 4$ & $400 \cdot 7$ & $373 \cdot 0$ & $417 \cdot 7$ & 0.86 & 0.89 & 0.96 & 0.89 \\
\hline BS-60-06-61-S & $53 \cdot 2$ & 0.647 & 368.5 & $384 \cdot 7$ & $405 \cdot 6$ & $376 \cdot 4$ & $426 \cdot 7$ & 0.86 & 0.90 & 0.95 & 0.88 \\
\hline
\end{tabular}

Lam et al. (2003)

\begin{tabular}{|c|c|c|c|c|c|c|c|c|c|c|c|}
\hline$x 4$ & 31.9 & 0.650 & $23 \cdot 7$ & $24 \cdot 3$ & $24 \cdot 6$ & 24.9 & 34.5 & 0.69 & 0.71 & 0.71 & 0.72 \\
\hline$\times 5$ & 31.9 & 0.650 & $23 \cdot 7$ & $24 \cdot 3$ & $24 \cdot 6$ & $24 \cdot 9$ & $36 \cdot 3$ & 0.65 & 0.67 & 0.68 & 0.69 \\
\hline Average & & & & & & & & 0.86 & 0.86 & 0.88 & 0.86 \\
\hline
\end{tabular}

Table 10. Proposed strength comparisons of columns subjected to high axial load level

whereas the average ratios of the code- predicted to measured strengths are 0.87 and 0.95 , respectively. The proposed stress block method, therefore, gives the same accuracy as the current codes in predicting flexural strength.

\section{Conclusion}

A total of 16 inverted T-shaped specimens were fabricated and tested to investigate the effects of strain gradient on the maximum and equivalent concrete stresses that can be developed in $\mathrm{RC}$ members under flexure. The specimens were divided into six groups, each of which consisted of columns with identical section properties and material strengths. One of the specimens in each group was concentrically loaded while the rest was/were eccentrically or horizontally loaded. Strain gradient effects on the maximum concrete stress were studied using $k_{3}$, the ratio of the maximum concrete stress developed under flexure to the concrete cube strength.

The effect of strain gradient on the equivalent concrete stress developed under flexure was investigated using the parameter $\alpha$, the ratio of the equivalent concrete stress to concrete cube strength.

The effects of strain gradient on the maximum and equivalent concrete stresses developed in flexure were studied by modifying the uniaxial stress-strain curve of concrete obtained from the concentrically loaded specimen, based on which the axial load and moment capacities evaluated for the eccentrically or horizontally loaded specimen were matched with the experimentally measured values. From the results obtained, it was found that the values of $k_{3}$ and $\alpha$ are larger than those obtained by 


\begin{tabular}{|c|c|c|c|c|c|c|c|c|c|c|c|}
\hline \multirow[t]{2}{*}{ Specimen code } & \multirow{2}{*}{$f_{\mathrm{c}}^{\prime}=0.8 f_{\mathrm{cu}}: \mathrm{MPa}$} & \multirow[t]{2}{*}{$P / A_{g} f_{c}^{\prime}$} & \multicolumn{5}{|c|}{ Moment: kNm } & \multirow{2}{*}{$\frac{(1)}{(5)}$} & \multirow{2}{*}{$\frac{(2)}{(5)}$} & \multirow{2}{*}{$\frac{(3)}{(5)}$} & \multirow{2}{*}{$\frac{(4)}{(5)}$} \\
\hline & & & $\begin{array}{l}M_{p} \\
(1)\end{array}$ & $\begin{array}{c}M_{\mathrm{ACl}} \\
(2)\end{array}$ & $\begin{array}{c}M_{\mathrm{EC}} \\
(3)\end{array}$ & $\begin{array}{c}M_{\mathrm{NZ}} \\
(4)\end{array}$ & $\begin{array}{l}M_{\mathrm{t}} \\
(5)\end{array}$ & & & & \\
\hline
\end{tabular}

Sheikh and Yeh (1990)

\begin{tabular}{|c|c|c|c|c|c|c|c|c|c|c|c|}
\hline F-6 & $27 \cdot 2$ & 0.750 & $126 \cdot 3$ & $133 \cdot 5$ & 134.7 & 133.5 & $145 \cdot 4$ & 0.87 & 0.92 & 0.93 & 0.92 \\
\hline D-7 & $26 \cdot 2$ & 0.780 & $116 \cdot 2$ & 121.0 & $123 \cdot 1$ & 121.0 & $133 \cdot 3$ & 0.87 & 0.91 & 0.92 & 0.91 \\
\hline$E-8$ & $25 \cdot 9$ & 0.780 & $121 \cdot 0$ & 128.4 & $129 \cdot 2$ & 128.4 & $129 \cdot 2$ & 0.94 & 0.99 & 1.00 & 0.99 \\
\hline F-9 & $26 \cdot 5$ & 0.770 & $123 \cdot 8$ & $130 \cdot 9$ & 131.6 & $130 \cdot 9$ & $152 \cdot 0$ & 0.82 & 0.86 & 0.87 & 0.86 \\
\hline$E-10$ & $26 \cdot 3$ & 0.770 & 121.9 & $130 \cdot 6$ & $131 \cdot 3$ & 130.6 & 132.7 & 0.91 & 0.98 & 0.99 & 0.98 \\
\hline$A-11$ & 27.9 & 0.740 & $130 \cdot 6$ & $139 \cdot 1$ & 139.7 & $139 \cdot 1$ & $135 \cdot 2$ & 0.96 & 1.03 & 1.03 & 1.03 \\
\hline E-13 & $27 \cdot 2$ & 0.740 & $126 \cdot 7$ & 134.9 & $136 \cdot 2$ & 134.9 & 128.0 & 0.99 & 1.05 & 1.06 & 1.05 \\
\hline D-14 & $26 \cdot 9$ & 0.750 & $122 \cdot 9$ & $126 \cdot 9$ & 128.8 & $126 \cdot 9$ & $116 \cdot 5$ & 1.05 & 1.09 & $1 \cdot 11$ & 1.09 \\
\hline D-15 & $26 \cdot 2$ & 0.750 & $123 \cdot 8$ & $124 \cdot 6$ & 124.6 & $124 \cdot 1$ & 134.5 & 0.92 & 0.93 & 0.93 & 0.92 \\
\hline
\end{tabular}

Sheikh and Khoury (1993)

\begin{tabular}{|c|c|c|c|c|c|c|c|c|c|c|c|}
\hline ES-13 & $32 \cdot 5$ & 0.760 & $130 \cdot 7$ & $139 \cdot 8$ & $141 \cdot 2$ & $140 \cdot 0$ & $163 \cdot 3$ & 0.80 & 0.86 & 0.86 & 0.86 \\
\hline FS-9 & $32 \cdot 4$ & 0.760 & 129.7 & 139.6 & 141.0 & 139.9 & $157 \cdot 2$ & 0.83 & 0.89 & 0.90 & 0.89 \\
\hline
\end{tabular}

Sheikh et al. (1994)

\begin{tabular}{|c|c|c|c|c|c|c|c|c|c|c|c|}
\hline AS-17 & $31 \cdot 3$ & 0.770 & $128 \cdot 3$ & $136 \cdot 2$ & $137 \cdot 4$ & $136 \cdot 4$ & $180 \cdot 2$ & 0.71 & $0 \cdot 76$ & $0 \cdot 76$ & 0.76 \\
\hline \multicolumn{12}{|c|}{ Nemecek et al. (2005) } \\
\hline N50 & $30 \cdot 0$ & 0.915 & $9 \cdot 9$ & $9 \cdot 5$ & $10 \cdot 9$ & $9 \cdot 4$ & $9 \cdot 6$ & 0.94 & 0.99 & $1 \cdot 14$ & 0.98 \\
\hline N100 & $30 \cdot 0$ & 0.900 & $10 \cdot 1$ & $9 \cdot 9$ & 11.4 & $9 \cdot 9$ & $9 \cdot 3$ & 1.08 & 1.06 & 1.23 & 1.06 \\
\hline N150 & $30 \cdot 0$ & 0.892 & $10 \cdot 2$ & $10 \cdot 2$ & $11 \cdot 6$ & $10 \cdot 1$ & $9 \cdot 3$ & 1.09 & $1 \cdot 10$ & $1 \cdot 25$ & 1.09 \\
\hline Average & & & & & & & & 0.92 & 0.96 & 1.00 & 0.90 \\
\hline
\end{tabular}

Table 11. Proposed strength comparisons of columns subjected

to ultra-high axial load level

previous researchers and those specified in current RC design codes. More importantly, it was found that $k_{3}$ and $\alpha$ are dependent on strain gradient but the variations are non-linear. The values of $k_{3}$ and $\alpha$ remain relatively constant at low strain gradient, but increase significantly with moderate strain gradient until they reach the maximum limits of about 1.3 and 1.15 respectively. It was also found that the values of $\alpha$ for concentrically loaded columns are very similar to those specified in the current design codes.

Based on the obtained values of $k_{3}$ and $\alpha$, empirical formulas were proposed for $k_{3}$ and $\alpha$ that incorporate strain gradient effects; the values of the other stress block parameters, $k_{1}, k_{2}, \beta$ and $\varepsilon_{\mathrm{cu}}$, were found to remain relatively constant at about 0.73 , $0.40,0.80$ and 0.0031 respectively. In order to verify the applicability of the proposed equivalent rectangular stress block parameters, they were used to predict the flexural strengths of RC beams and columns subjected to various axial load levels in tests carried out by previous researchers. The predicted strengths were compared with experimental strengths and theoretical strengths calculated using current RC design codes. The comparisons show that the proposed strain-gradient-dependent equivalent concrete stress block is more accurate in predictions of the flexural strength of RC beams and columns subjected to low and medium axial load levels than current codes. The improvements are $6 \%$ for RC beams and $18 \%$ for columns subjected to a medium axial load level. However, the proposed parameters do not improve the flexural strength prediction of RC columns subjected to high and ultra-high axial load levels because the strain gradient developed in these columns is very small.

Lastly, it is worth noting that this paper has only considered the beneficial effects of strain gradient on the flexural strength design of RC beams and columns; it does not comment on the suitability 
of implementing the proposed equations on $\alpha$ and $\beta$ in existing design codes. This is because the current study did not consider any variability (e.g. material strength) and uncertainty, which should also be taken into account when establishing design clauses.

\section{Acknowledgements}

A research grant from the Seed Funding Programme for Basic Research (account code 10401445) of The University of Hong Kong (HKU) for the work presented here is gratefully acknowledged. The authors gratefully thank the Department of Civil and Structural Engineering, Hong Kong Polytechnic University (PolyU), where most of the experimental tests were conducted. The support of the technical staff in the structural laboratory of PolyU and the Department of Civil Engineering of HKU is also greatly appreciated.

\section{REFERENCES}

ACI (American Concrete Institute) (2008) ACI 318: Building code requirements for reinforced concrete and commentary ACI 318M-08. ACI, Farmington Hills, MI, USA.

Ahn JM and Shin SW (2007) An evaluation of ductility of high-strength reinforced concrete columns subjected to reverse cyclic loads under axial compression. Magazine of Concrete Research 59(1): 29-44.

Ashour SA (2000) Effect of compressive strength and tensile reinforcement ratio on flexural behaviour of high-strength concrete beams. Engineering Structures 25(8): 1083-1096.

Arslan G (2010) Shear strength of reinforced concrete slender beams. Proceedings of the Institution of Civil Engineers Structures and Buildings 163(3): 195-205.

Arslan MH, Yuksel I and Kaltakci MY (2010) An investigation on global ductility of strengthened RC frames, Proceedings of the Institution of Civil Engineers - Structures and Buildings 163(3): 177-194.

Baczkowski BJ and Kuang JS (2008) A new approach to testing concrete coupling beams subjected to reversed cyclic loading. Magazine of Concrete Research 60(4): 301-309.

Bai ZZ and Au FTK (2008) Ductility of symmetrically reinforced concrete columns. Magazine of Concrete Research 61(5): 345-357.

Bukhari IA, Vollum RL, Ahmad S and Sagaseta J (2010) Shear strengthening of reinforced concrete beams with CFRP. Magazine of Concrete Research 62(1): 65-77.

CEN (European Committee for Standardization) (2004) BS EN 1992: Eurocode 2: Design of concrete structures. Part 1-1: general rules and rules for buildings. CEN, Brussels, Belgium.

Chen Y and May IM (2009) Reinforced concrete members under drop-weight impacts. Proceedings of the Institution of Civil Engineers - Structures and Buildings 162(1): 45-56.

Choi E, Park J, Nam TH and Yoon SJ (2009) A new steel jacketing method for RC columns. Magazine of Concrete Research 61(10): 787-796.

Clark LE, Gerstle KH and Tulin LG (1967) Effect of strain gradient on the stress-strain curve of mortar and concrete. $A C I$ Journal 64(50): 580-586.

Debernardi PG and Taliano M (2002) On evaluation of rotation capacity for reinforced concrete beams. ACI Structural Journal 99(3): 360-368.

Do Carmo RNF and Lopes SM (2006) Required plastic rotation of $\mathrm{RC}$ beams. Proceedings of the Institution of Civil Engineers - Structures and Buildings 159(2): 77-85.

Fathifazl G, Razaqpur AG, Isgor OB et al. (2009) Shear strength of reinforced recycled concrete beams without stirrups. Magazine of Concrete Research 61(7): 477-490.

Han TH, Stallings JM, Cho SK and Kang YJ (2010) Behaviour of a hollow RC column with an internal tube. Magazine of Concrete Research 62(1): 25-38.

Ho JCM and Pam HJ (2003) Influence of transverse steel configuration on post-elastic behaviour of high-strength reinforced concrete columns. Transactions of the Hong Kong Institution of Engineers 10(2): 1-9.

Ho JCM and Pam HJ (2010) Deformability evaluation of highstrength reinforced concrete columns. Magazine of Concrete Research 62(8): 569-583.

Hognestad E (1957) Confirmation of inelastic stress distribution in concrete. Proceedings of ASCE 83(2): 1-17.

Hognestad E, Hanson NW and McHenry D (1955) Concrete stress distribution in ultimate strength design. ACI Journal 52(4): 455-479.

Ibrahim HHH and MacGregor JG (1996) Flexural behavior of laterally reinforced high-strength concrete sections. $A C I$ Structural Journal 93(6): 674-684.

Ibrahim HHH and MacGregor JG (1997) Modification of the ACI rectangular stress block for high-strength concrete. $A C I$ Structural Journal 94(1): 40-48.

Inel M, Aschheim MA and Pantazopoulou SJ (2007) Seismic deformation capacity indices for concrete columns: model estimates and experimental results. Magazine of Concrete Research 59(4): 297-310.

Inel M, Bilgin H and Ozmen HB (2008) Seismic capacity evaluation of school buildings in Turkey. Proceedings of the Institution of Civil Engineers - Structures and Buildings 161(3): 147-159.

Jaafar K (2008) Shear behaviour of reinforced concrete beams with confinement near plastic hinges. Magazine of Concrete Research 60(9): 665-672.

Jones J and Fraser R (2009) Ship impact on concrete offshore platform legs. Proceedings of the Institution of Civil Engineers - Structures and Buildings 162(1): 21-25.

Kaar PH, Hanson NW and Capell HT (1978) Stress-strain characteristics of high strength concrete. Douglas McHenry International Symposium on Concrete and Concrete Structures. American Concrete Institute, Farmington Hills, MI, USA, pp. 161-185.

Kim TH, Kim YJ and Shin HM (2007) Seismic performance assessment of reinforced concrete bridge columns under variable axial load. Magazine of Concrete Research 59(2): $87-96$. 
Kriz LB (1959) Ultimate strength criteria for reinforced concrete. Proceedings of ASCE 85(3): 95-110.

Lam SSE, Wu B, Wong YL et al. (2003) Drift capacity of rectangular reinforced concrete columns with low lateral confinement and high-axial load. Journal of Structural Engineering ASCE 129(6): 733-742.

Lam SSE, Wu B, Liu ZQ and Wong YL (2008) Experimental study on seismic performance of coupling beams not designed for ductility. Structural Engineering and Mechanics 28(3): 317333.

Lu WY, Lin IJ and Hwang SJ (2009) Shear strength of reinforced concrete corbels. Magazine of Concrete Research 61(10): 807-813.

Marefat MS, Khanmohammadi M, Bahrani MK and Goli A (2005) Cyclic load testing and numerical modelling of concrete columns with substandard seismic details. Computers and Concrete 2(5): 367-380.

Marefat MS, Khanmohammadi M, Bahrani MK and Goli A (2006) Experimental assessment of reinforced concrete columns with deficient seismic details under cyclic load. Advances in Structural Engineering 9(3): 337-347.

Mansur MA, Chin MS and Wee TH (1997) Flexural behavior of high-strength concrete beams. ACI Structural Journal 94(6): 663-673.

Mattock AH, Kriz LB and Hognestad E (1961) Rectangular concrete stress distribution in ultimate strength design. $A C I$ Journal 32(8): 875-927.

Mo YL and Wang SJ (2000) Seismic behavior of RC columns with various tie configurations. Journal of Structural Engineering, ASCE 126(10): 1122-1130.

Nemecek P, Padevet B, Patzak B and Bittnar Z (2005) Effect of transversal reinforcement in normal and high strength concrete columns. Materials and Structures 38(7): 665-671.

Oehlers DJ, Haskett M, Mohamed Ali MS and Griffith MC (2010) Moment redistribution in reinforced concrete beams, Proceedings of the Institution of Civil Engineers - Structures and Buildings 163(3): 165-176.

Pam HJ and Ho JCM (2001) Flexural strength enhancement of confined reinforced concrete columns. Proceedings of the Institution of Civil Engineers - Structures and Buildings 146(4): $363-370$.

Pam HJ and Ho JCM (2009) Length of critical region for confinement steel in limited ductility high-strength reinforced concrete columns. Engineering Structures 31(12): 2896-2908.

Pam HJ, Kwan AKH and Islam MS (2001) Flexural strength and ductility of reinforced normal- and high-strength concrete beams. Proceedings of the Institution of Civil Engineers Structures and Buildings 146(4): 381-389.

Pecce M and Fabbrocino G (1999) Plastic rotation capacity of beams in normal and high-performance concrete. $A C I$ Structural Journal 96(2): 290-296.

Sebastian W and Zhang C (2008) Analysis of concrete structures across the ductility spectrum. Magazine of Concrete Research 60(9): 685-690.
Sheikh SA and Khoury SS (1993) Confined concrete columns with stubs. ACI Structural Journal 90(4): 414-431.

Sheikh SA and Yeh CC (1990) Tied concrete columns under axial load and flexure. Journal of Structural Division, ASCE 116(10): 2780-2801.

Sheikh SA, Shah DV and Khoury SS (1994) Confinement of highstrength concrete columns. ACI Structural Journal 91(1): $100-111$.

Shim CS, Chung YS and Han JH (2008) Cyclic response of concrete-encased composite columns with low steel ratio. Proceedings of the Institution of Civil Engineers - Structures and Buildings 161(2): 77-89.

Sim Jl, Yang KH and Shim HJ (2009) Test on seismic strengthening of RC columns using wire rope and T-plate units. Magazine of Concrete Research 61(10): 823-836.

Smith RG and Orangun CO (1969) Evaluation of the stress-strain curve of concrete in flexure using method of least squares. ACI Journal 66(44): 805-822.

SNZ (Standards New Zealand) (2006) NZS 3101: Concrete Structures. Part 1: The design of concrete structures. SNZ, Wellington, New Zealand.

Soliman MTM and Yu CW (1967) The flexural stress-strain relationship of concrete confined by rectangular transverse reinforcement. Magazine of Concrete Research 19(61): 223 238.

Spence R (2008) Earthquake loss estimation for reinforced concrete buildings: some problems. Magazine of Concrete Research 60(9): 701-707.

Sturman GM, Shah SP and Winter G (1965) Effects of flexural strain gradients on microcracking and stress-strain behavior of concrete. ACI Journal 62(50): 805-822.

Supaviriyakit T, Pimanmas A and Warnitchai P (2007) Cyclic response of non-seismically detailed interior RC beamcolumn connection with varying column tributary area. Magazine of Concrete Research 59(5): 351-365.

Swartz SE, Nikaeen A, Narayan BHD, Periyakaruppan N and Refai TME (1985) Structural bending properties of high strength concrete. ACI Special Publication 87(9): 147-178.

Tabsh SW (2006) Elimination of the effect of strain gradient from concrete compressive strength test results. Computers and Concrete 3(6): 375-388.

Tan TH and Nguyen NB (2004) Determination of stress-strain curves of concrete from flexure tests. Magazine of Concrete Research 56(4): 243-250.

Tan TH and Nguyen NB (2005) Flexural behavior of confined high-strength concrete columns. ACI Structural Journal 102(2): 198-205.

Tao Z and Yu Q (2008) Behaviour of CFRP-strengthened slender square RC columns. Magazine of Concrete Research 60(7): 523-533.

Watson S and Park R (1994) Simulated seismic load tests on reinforced concrete columns. Journal of Structural Engineering, ASCE 120(6): 1825-1849.

Whitney CS (1940) Plastic theory of reinforced concrete design. Proceedings of ASCE 66(10): 1749-1780. 
Wu YF, Oehlers DJ and Griffith MC (2004) Rational definition of the flexural deformation capacity of RC column sections. Engineering Structures 26(5): 641-650.

Xiao X, Guan FL and Yan S (2008) Use of ultra-high-strength bars for seismic performance of rectangular high-strength concrete frame columns. Magazine of Concrete Research 60(4): 253259.
Yi ST, Kim JHJ and Kim JK (2002) Effect of specimen sizes on ACI rectangular stress block for concrete flexural members. ACI Structural Journal 99(5): 701-708.

Zhou W and Zheng WZ (2010) Experimental research on plastic design method and moment redistribution in continuous concrete beams prestressed with unbonded tendons. Magazine of Concrete Research 62(1): 51-64.

\section{WHAT DO YOU THINK?}

To discuss this paper, please email up to 500 words to the editor at journals@ice.org.uk. Your contribution will be forwarded to the author(s) for a reply and, if considered appropriate by the editorial panel, will be published as a discussion in a future issue of the journal.

Proceedings journals rely entirely on contributions sent in by civil engineering professionals, academics and students. Papers should be 2000-5000 words long (briefing papers should be 1000-2000 words long), with adequate illustrations and references. You can submit your paper online via www.icevirtuallibrary.com/content/journals, where you will also find detailed author guidelines. 